\title{
الحوار في ضوء القرآن والسنة
}

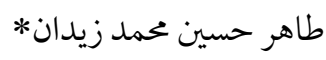

\section{Abstract \\ Dialogue in the Light of the Qur'ān and Sunnah}

Tahir Hussain Muhammad Zaidan*

This article discusses different aspects of dialogue in the light of the Qur'ān and Sunnah. The Qur'ān calls for dialogue and the biography of the Prophet Muhammad tells that he interacted with polytheists, hypocrites, and the people of the book. Therefore, dialogue with other religions is not just a forced choice imposed by geographical, social, or political realities; rather it is the best strategy that the Prophet (PBUH) employed during the Meccan and Medina phases of Islamic preaching. However, in the modern period, some people may accuse Islam of opposing interfaith dialogue. This study highlights that such accusations are baseless and that Islam teaches its followers to have dialogue with the adherents of other religions in the best possible way. Moreover, this study identifies the ways to promote and strengthen interfaith dialogue in the modern age.

\section{Keywords}

Qur'ān, sunnah, interfaith dalogue, peaceful coexistence.

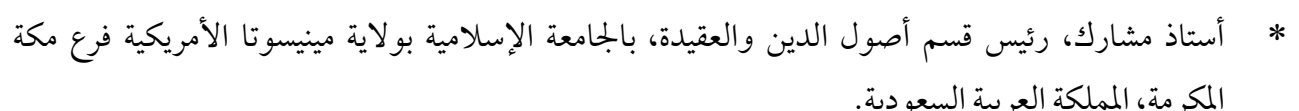

* Associate Professor, Head of Department of Islamic Studies, Islamic University of Minnesota America, Mecca Campus, Kingdom of Saudi Arabia. 
تعيش الأمة الإسلامية حالة عصيبة من الزمن، اختلط فيها الو اقع بالخيال، الأمل باليأس، ومع تفرق أبناء الأمة ظهرت الحاجة للتقريب بين المسلمين، فضلا عن ضرورة الوحدة، ولكن هذا

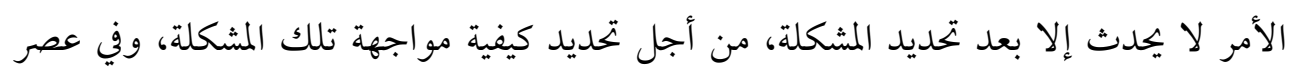
تداخلت فيه المشاكل الدولية بالمشاكل الداخلية، فيجب على المسلمين العودة إلى جذورهم الدينية الحقيقية، وتحديد الخطر الأكبر الذي يوجهرم.

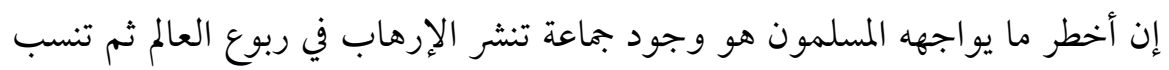
نفسها للإسلام فشوهت الإسلام والمسلمين، ثم حدث ما سُمي في الغرب الأوروبي "الإسلاموفوبيا"(1)، أو الخوف من الإسلام، وهي حالة من الهلع من أي مسلم، من أي اسم فيه

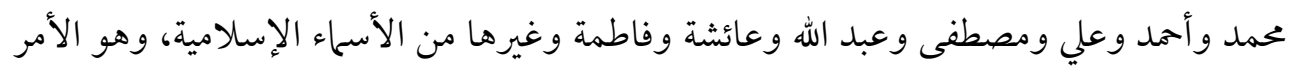
الذي لا يجب السكوت عليه، بل يجب مواجهة الأمر بالحمكة والعقل والتقارب بين المسلمين، والحوار فيها بينهم قبل الحوار مع غيرهم، وهذا يستلزم من المسلمين العودة لأصولهم القرآنية الربانية، والعمل على تطبيقها في أرض الواقع. لابد أن يبدأ المسلمون الحوار فيها بينهم الآن دون تأخير، والعودة للميراث الإسلامي التساحي الشامل لكل مناحي الحياة، فالله يطلب الاعتصام، فلابد من الاعتصام لقد جاء الإسلام

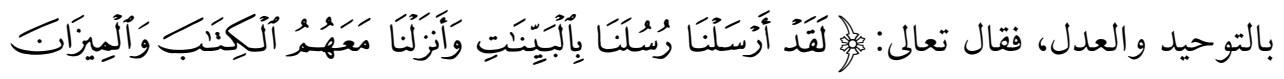

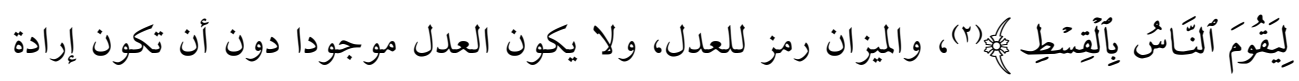
الإنسان حرة مستقلة، والعدل يشمل الجميع ليبدأ الحوار، والحضارة الإسلامية هي أم الحضارة

مصطلح يعني الخوف من الإسلام، لأن كلمة فوبيا تعني الخوف المسيطر على الإنسان بسبب موقف أو شيء معين، 
المعاصرة، أخذ الغرب منها ثم بنى عليها، وحاولوا تشويه الإسلام، على أنه وبالرغم من الحملات

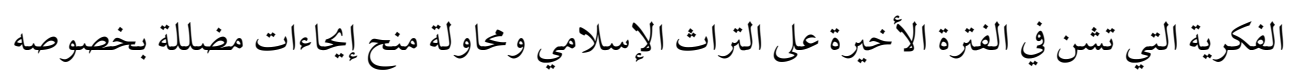

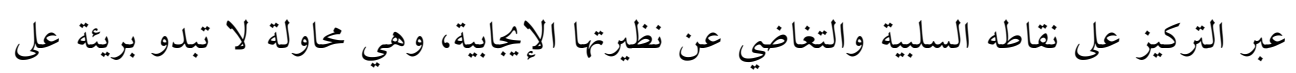
الإطلاق، حيث تسعى لفصل شعوب الشرق عن تراثها الأقرب.

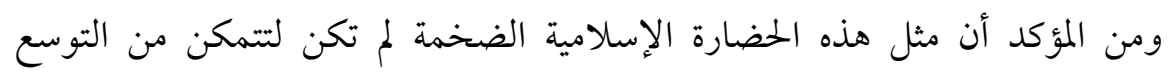
والاستقرار كل هذه الفترات التاريخية دون الاعتماد على الحوار مع النفس والآخر، والذي مثل في الكثير من المناطق الإسلامية الأكثرية الجحاهيرية، كما أن سقوط الحضارة الإسلامية في فترات الترات التأخر التي عاشتها، هو ما أدى لتجاوز المسلمين على مسلماتهم الحضارية التي مثلت أهم أسباب تفوقهم ما أدى لحالة التراجع والتشوه الحضاري الذي تعاني منه معظم دولهم.

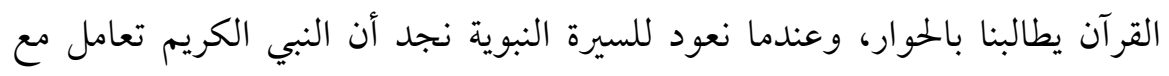

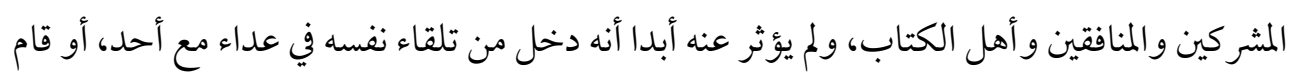

$$
\text { بالحرب، فالحروب النبوية كانت في الأصل حروبا دفاعية. }
$$

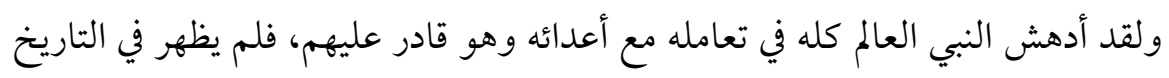

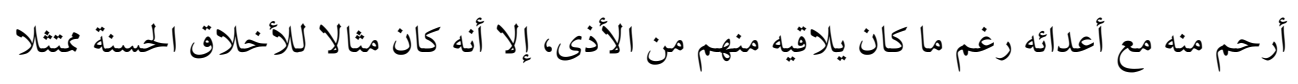

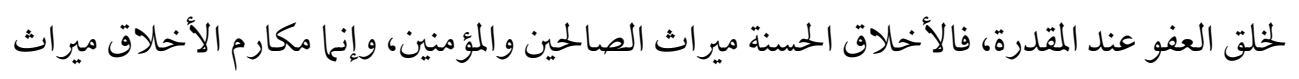
المؤمن(r). ورسول الله ماسك بلجامها متمسك بها داعٍ إليها ومتممٌّ ها "إنما بعثت لأتمم مكارم

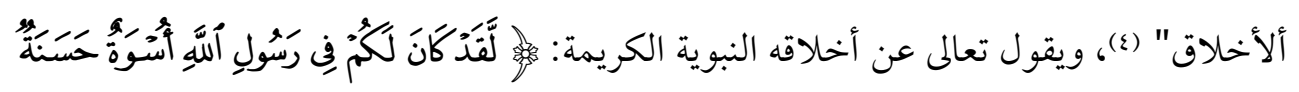

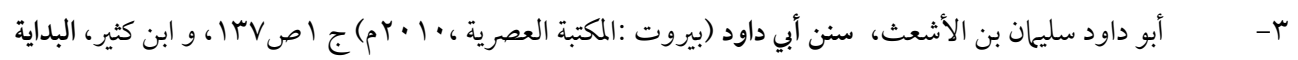

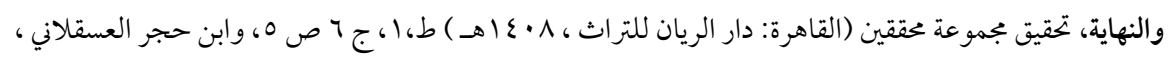

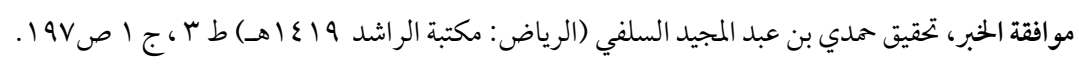

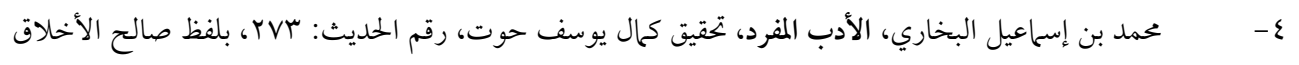

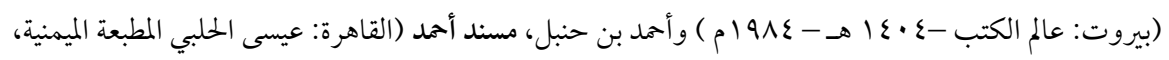




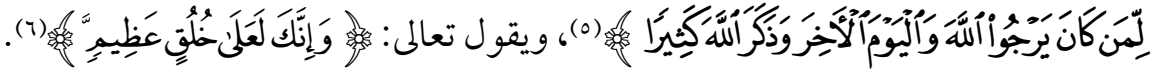
والرسول القدوة كان يحاور كل الناس مؤمنهم وكافرهم ومنافقهم، إذن لا يمثل الحوار مع الآخر مجرد خيار اضطراري يفرضه الو اقع الجغرافي أو الاجتماعي أو حتى السياسي، وإنها هو

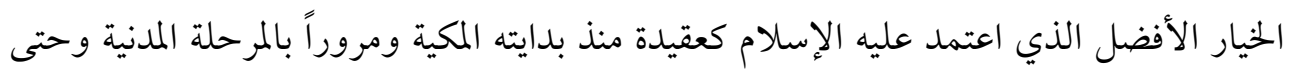
خلال المراحل التاريخية اللاحقة في عهد الخلفاء الراشدين، أو في ظل الدولة الأموية أو العباسية، ومن جاء من بعدهم من الدول الاسلامية. لقد كان خيار الحوار هو الأكثر قرباً من المنهج الإسلامي والذي سعى النبي صلى الله عليه وسلم من خلاله لتصحيح فكر المجتمع القبلي والعصبية القبلية، وكان طرح الحوار مع الآخر الديني والذي كان يتضمن كذلك في بعض الأحيان الآخر السياسي، الوسيلة البديلة للصراعات القائمة على العصبيات.

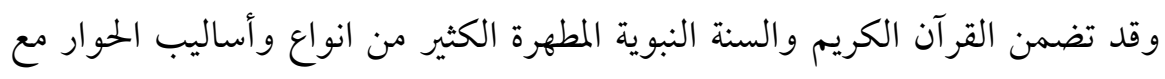
الآخر الديني كالنصارى واليهود وحتى الوثنيين، وشملت في بعض الأحيان المديح لهذا الآخر بل إن هذه الحوارات شملت كذلك تفاهمات بين الخلفاء الراشدين وخلفاء الأمويين والعباسيين وبين أبناء الأديان والمذاهب الفكرية المخالفة والذين كانوا يعيشون تحت ماية الدولة.

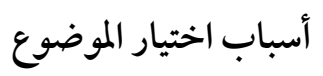

(1) يعد أسلوب الحوار أحد أهم الوسائل التي تملكها الأمة كما يملكها الفرد على حد سواء للتو اصل مع الآخرين، فالحوار نمط حياة وأسلوب تفكير وقد أولى القرآن الكريم عناية كبيرة للحوار، فهو الأسلوب الغالب في قصص الأمم السابقة، وهو الأداة الأولى للأنبياء وأتباعهم في نشر الدعوة .

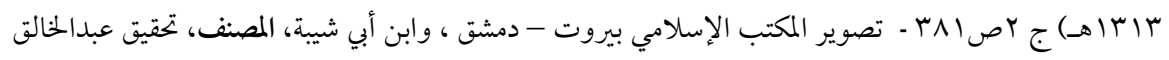

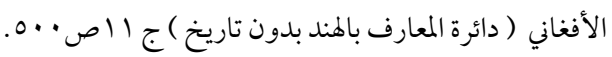

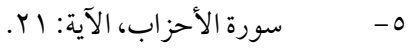

$$
\begin{aligned}
& \text { 1- سورة القلم، الآية: ع. }
\end{aligned}
$$


(Y) الحوار هو الوسيلة الأولى في عرض مسائل العقيدة، وقد لوحظ أن ساحة الحوار تكاد ترتبط بالشخصية الإنسانية ولذا كانت شاملة، كما لوحظ أن موضوعاته تكاد تنحصر في موضوع الرسالة ومدى قرب الناس وبعدهم عنها، ولهذا كانت هذه الدراسة تركز

$$
\text { على أسلوب الحوار في القرآن والسنة. }
$$

(r) هذا العصر يشهد اتهامات شتى للإسلام بأن تعاليمه تعاليم جامدة لا حوار فيها مانسا

$$
\text { حتم علينا إبراز الحوار في تعاليم الإسلام وانفتاحه على الآخر. }
$$

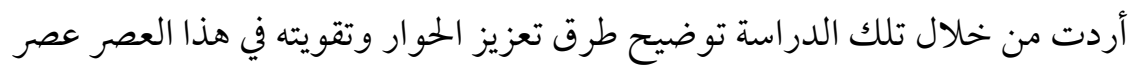

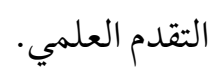

المبحث الأول: مفهوم الحوار وأهدافه وآدابه، و يشتمل على ثلاثة مطالب.

$$
\text { المطلب الأول: مفهوم الحوار لغة واصطلاحا }
$$

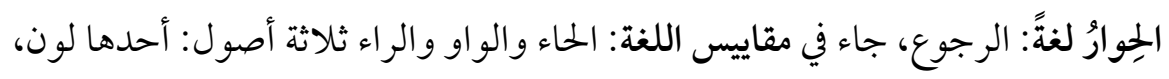

$$
\text { والآخَر الرُّجوع، والثالث أن يدور الشيء دَوْرَاً. }
$$

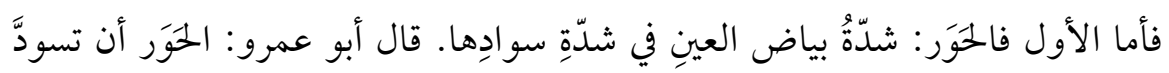

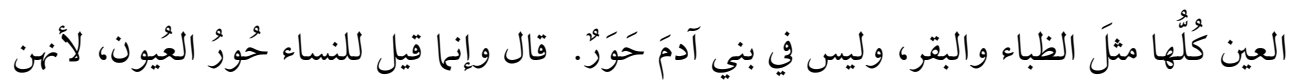

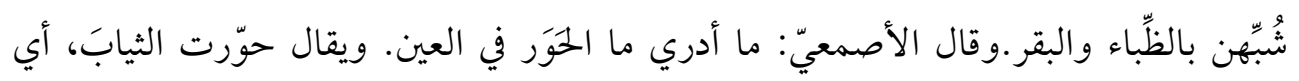

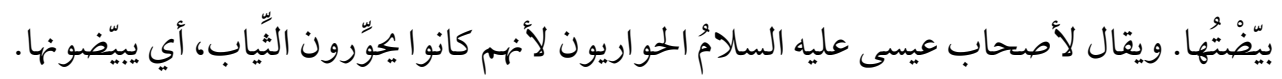

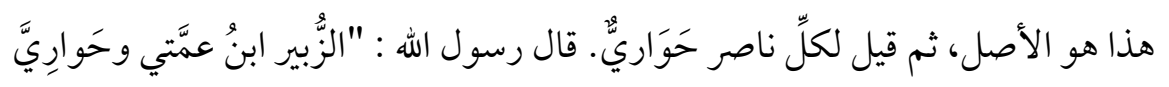

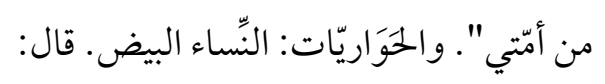

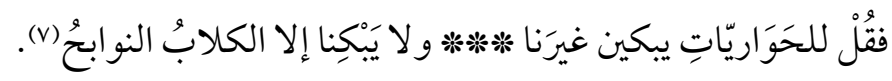

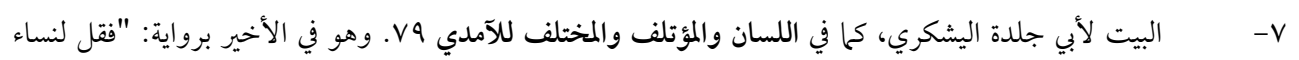
المصر". 


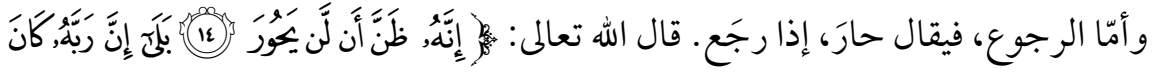

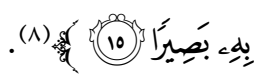
والعرب تقول: "الباطلُ في حُورِ" أَيْ رَجْعِ ونَقْصِ، وكلُّ نقص ورجوع حُورٌ.

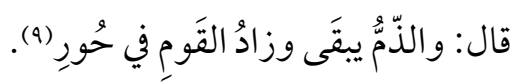

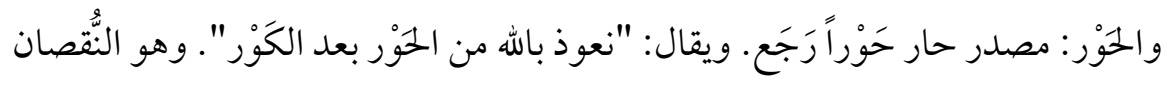
بعد الزيادة.

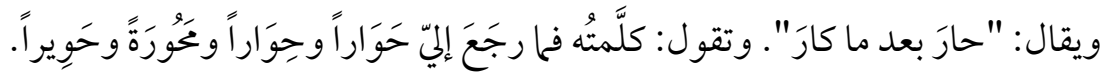

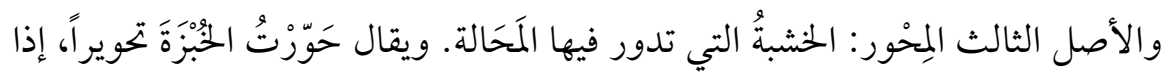

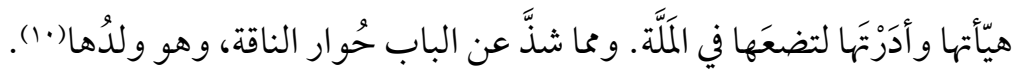

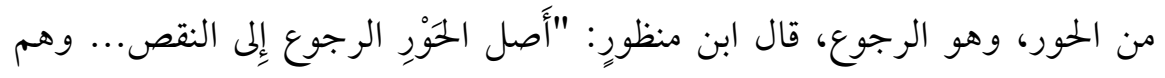

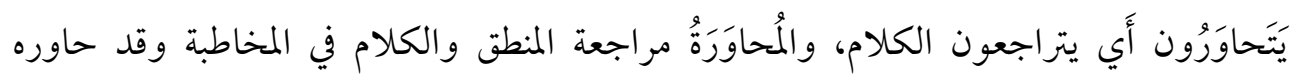

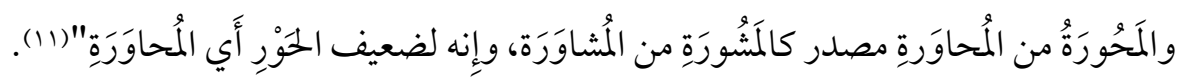

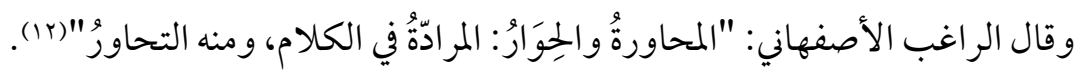

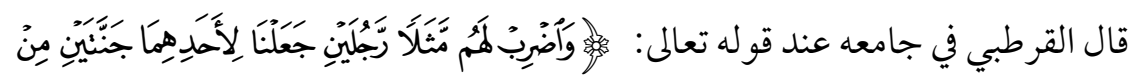

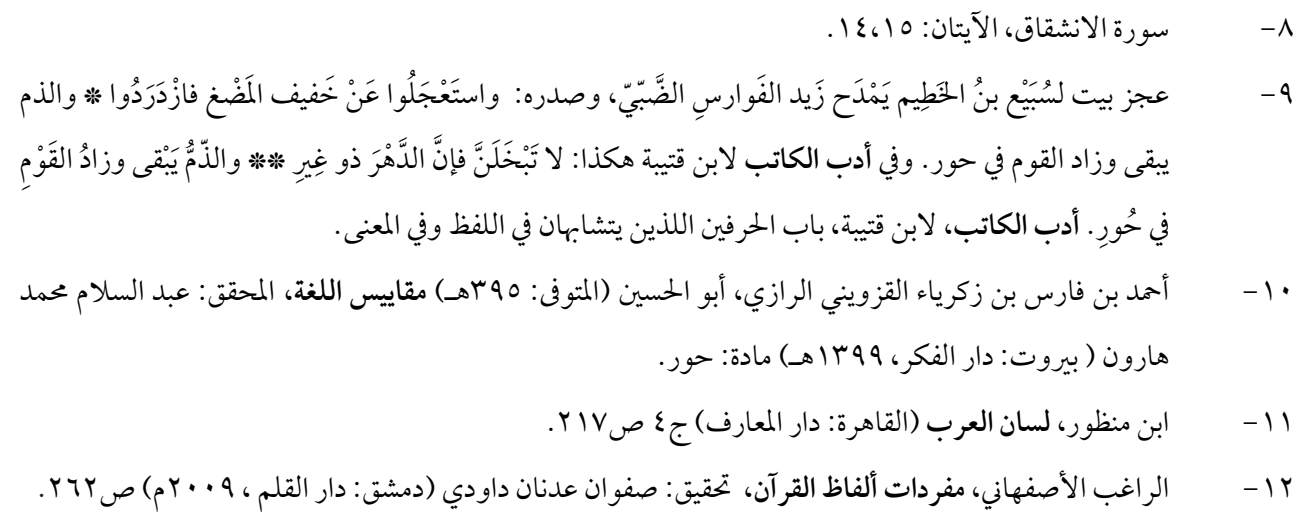




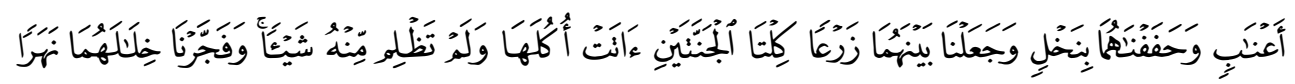

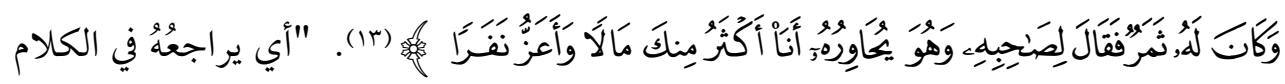

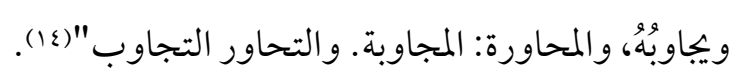

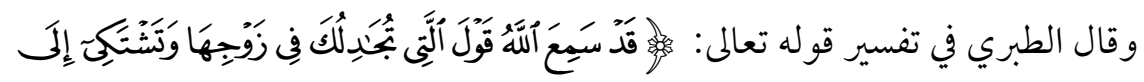

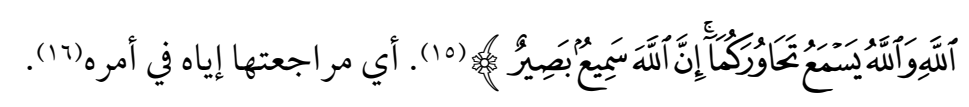

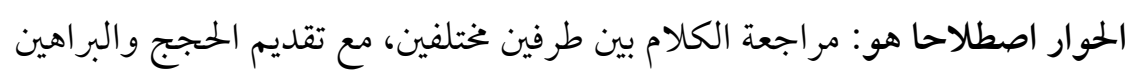

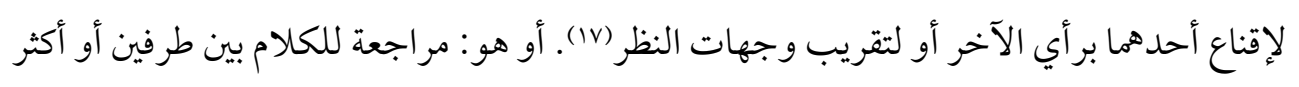

$$
\text { دون وجود خصومة بينهم بالضرورة (1) . }
$$

فالحوار إذن هو تداول الكلام بين أكثر من طرف في قضية أو قضايا معينه لمحاولة الإقناع

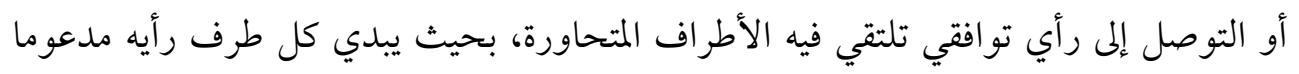

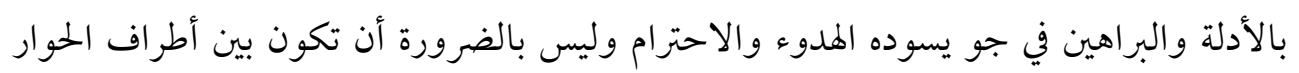

$$
\text { خصومة. }
$$

والحوار بهذا المفهوم سبيل ناجح للتفاهم والإقناع والتوصل إلى نتائج إيجابية في نهاية

$$
\begin{aligned}
& \text { المطاف أو التوقف عند تعذر ذلك بلا ضرر، ويتداخل كثيرا مع الجدل والمناظرة. } \\
& \text { الفرق بين الحوار والجدل والمناظرة }
\end{aligned}
$$

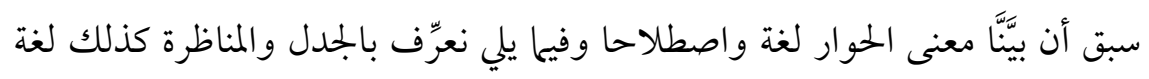

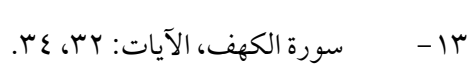

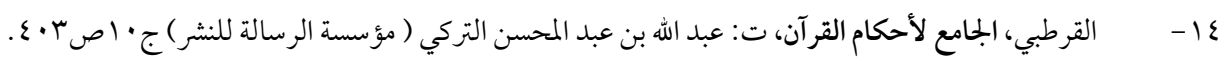

$$
\begin{aligned}
& \text { 10 - - إس سورة المجادلة، الآية: } 1 . \\
& 17 \text { - - - ابن جرير الطبري، جامع البيان في تفسير آي القرآن (القاهرة : دار ابن الجوزي) تفسير سورة المجادلة، الآية الأولى. }
\end{aligned}
$$

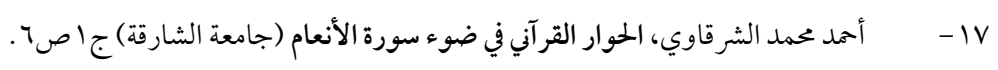

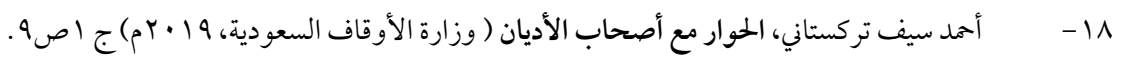




$$
\text { واصطلاحا، لنتو صل إلى معرفة الفرق بين هذه الكلمات المتقاربة. }
$$

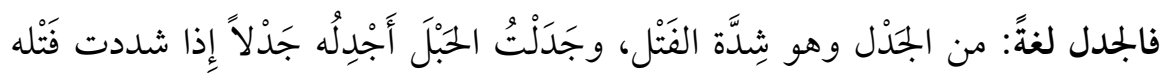

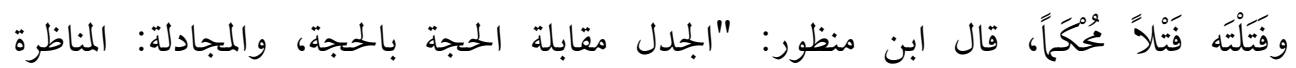

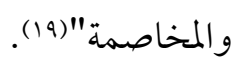

واصطلاحاً: الجددل هو القياس المؤلف من المشهورات والمسلمات، والغرض منه إلزام

الخصم وإقحام من هو قاصر عن إدر اك مقدمات البرهان، ودفع المرء خصمه عن إفساد قوله بحجة

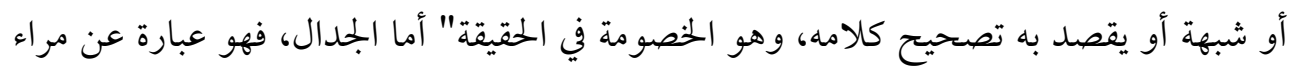

يتعلق بإظهار المذاهب وتقريرها (·r)، وهذا هو الفرق بينه وبين الجدل، وهو نوعان: مذموم، وهو

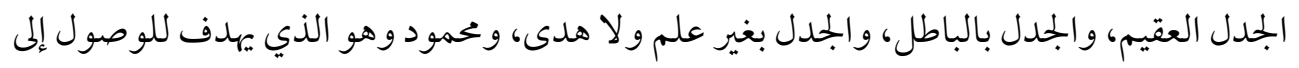

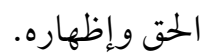

أما المناظرة في اللغة فتدور حول النظر والتأمل والنظير الشبيه والمثيل (r):

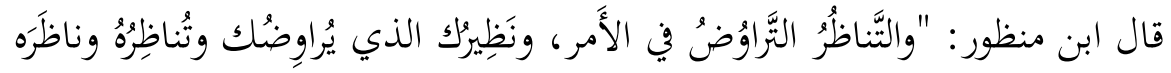

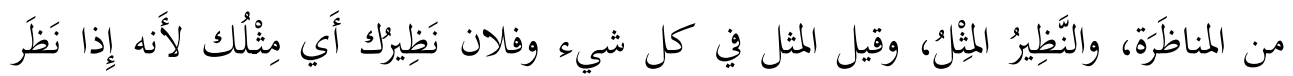

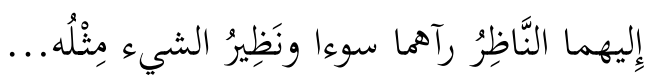

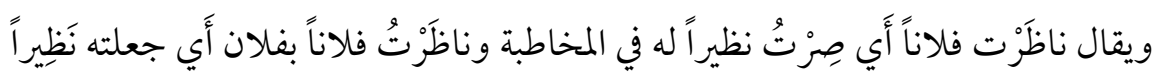

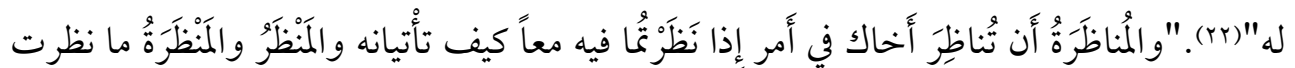

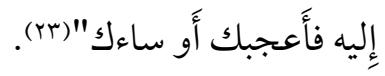

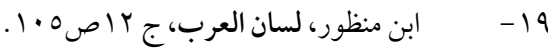

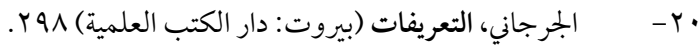

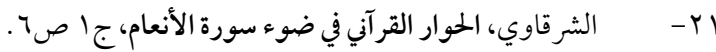

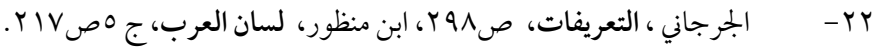

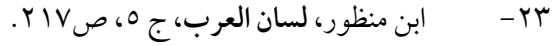


فالمناظرة تفيد النظر والتفكر في الأمور والبحث عن الحق عن طريق المحاورة مع الآخرين، وهي محاورة بين طرفين حول موضوعِ لكل منها وجهةٌ نظر فيه تخالف وجهةَ نظر الآخر

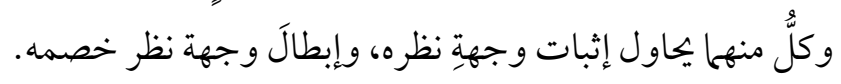
ومن هنا يمكن لنا أن نفرق بين هذه المصطلحات بأن :

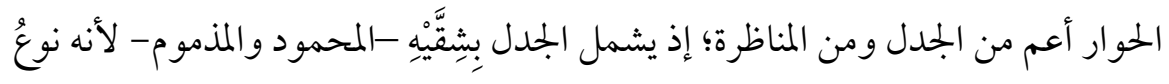
من الحوار كما يشملُ المناظرةَ باعتبارها طريقةً من طرقه.

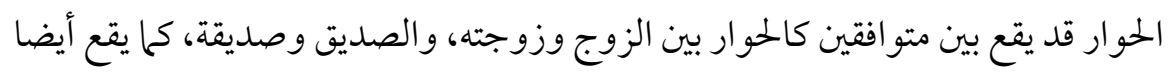
بين المختلفين في الرأي أو الاعتقاد، ولكنه يتَّسم بطريقته المادئة.

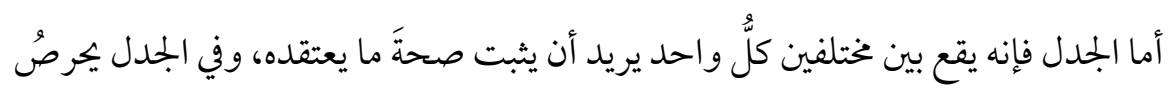

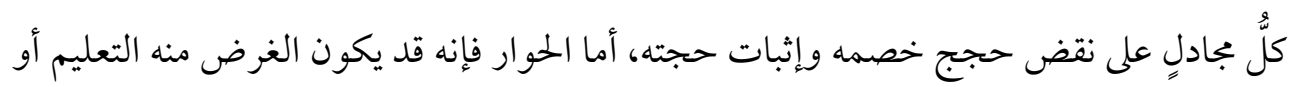

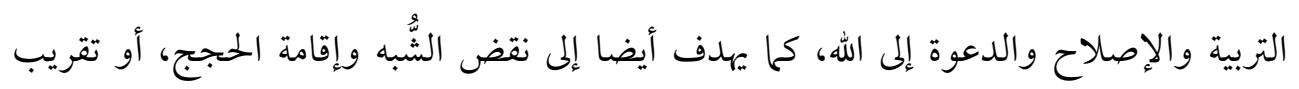
وجهات النظر أو التعارف أو التآلف أو الاستيضاح والاستبيان.

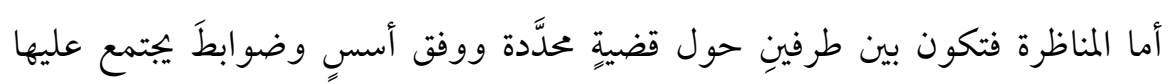

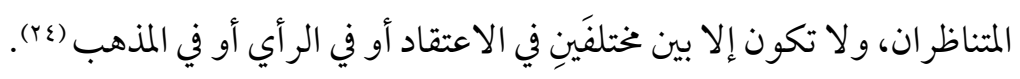
والحوار بمفهومه الشامل لا غنى عنه، فهو مفتاح القلوب، وطريق غخاطبة العقول، وسبيل الإقناع وأسلوب التفاهم والتواصل ونبراس الإصلاح والدعوة، وهو مجال واسع لإبداء

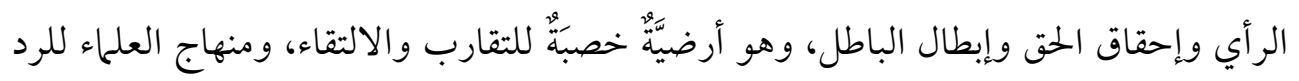

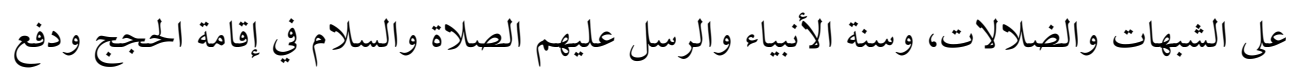
الشبه مع أقوامهم، والحاجة إليه كبيرة في عصرنا الحاضر لتقارب الزمن، وطي المسافات، وتداخل

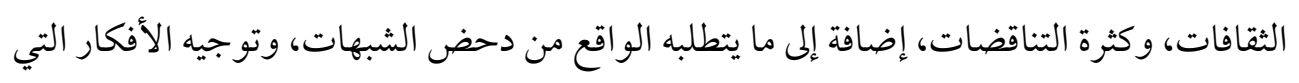

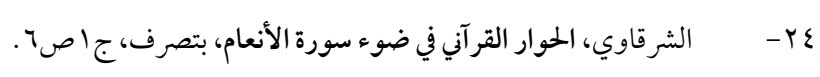




$$
\text { تعصف بشباب الأمة، مما أورثته التقنيات الجديدة، والشبكات العالمية، وغيرها. }
$$

( ) إقامة الحجة: الغاية من الحوار إقامة الحجة ودفع الشبهة والفاسد من القول والرأي.

$$
\text { والسير بطرق الاستدلال الصحيح للوصول إلى الحت. }
$$

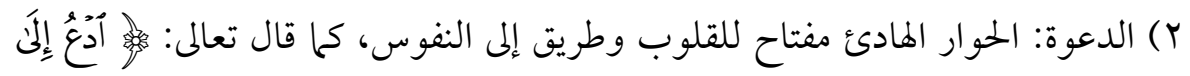

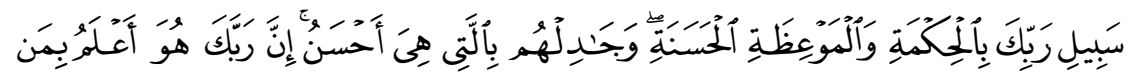

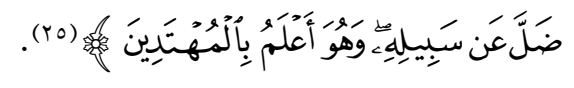

r) تقريب وجهات النظر : من ثمرات الحوار تضييق هوة الخلاف، وتقريب وجهات النظر،

$$
\text { وإيباد حل وسط يرضي الأطر اف في زمن كثر فيه التباغض والتناحر. }
$$

ع) كشف الشبهات والرد على الأباطيل، لإظهار الحت وإزهاق الباطل: كما قال تعالى:

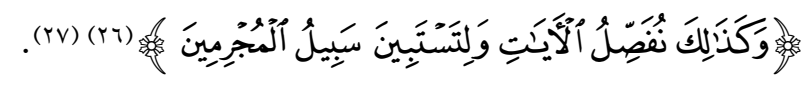

$$
\text { الأصول و القواعد الرئيسة التي تضبط مسار الحوار }
$$

الأصل الأول: الوصول إلى الحق: فلا بد من التجرد في طلب الحق، والحذر من التعصب

$$
\text { والهوى، وإظهار الغلبة والمجادلة بالباطل. }
$$

يقول الإمام الغزالي عند ذكره لعلامات طلب الحق: "أن يكون في طلب الحق كناشد ضالة، لا يفرّق بين أن تظهر الضالة على يده، أو على يد من يعاونه، ويرى رفيقه معينًا لا خصمًا،

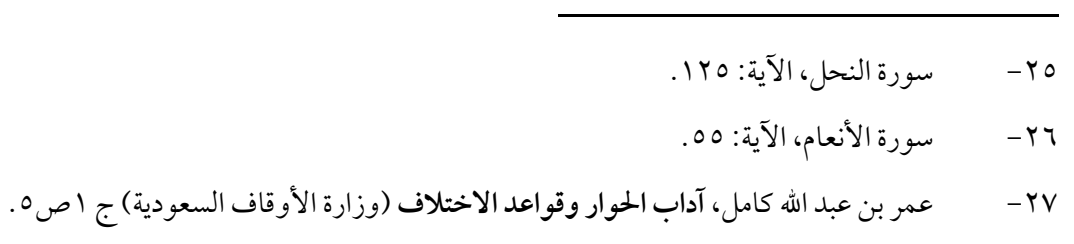




$$
\text { ويشكره إذا عرفه الخطأ و أظهر له الحق"(rN). }
$$

الأصل الثاني: تحديد الهدف والقضية التي يدور حولها الحوار، فإن كثيرًا من الحوارات

$$
\text { تتحول إلى جدل عقيم سائب ليس له نقطة محددة ينتهي إليها. }
$$

الأصل الثالث: الاتفاق على أصل يرجع إليه، و المرجعية العليا عند كل مسلم هي: الكتاب

والسنة، والضوابط المنهجية في فهم الكتاب والسنة. وقد أمر الله بالرد إليها فقال سبحانه: فئهَان

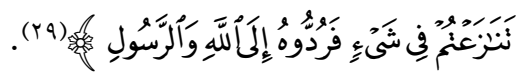

فالاتفاق على منهج النظر والاستدلال قبل البدء في أي نقاش علمي يضبط مسار الحوار

ويوجهه نحو النجاح، إذ إن الاختلاف في المنهج سيؤدي إلى الدوران في حلقة مفرغة لا حصر لها

$$
\text { ولاضابط. }
$$

الأصل الرابع: عدم مناقشة الفرع قبل الاتفاق على الأصل فلا بد من البدء بالأهم من

الأصول وضبطها والاتفاق عليها، ومن ثم الانطلاق منها لمناقشة الفروع والحوار حولها(·r).

$$
\text { المطلب الثالث: آداب الحوار }
$$

آدابُ الحوار التي تتعلق بنفسية المحاور وشخصه، وهناك ظروف نفسية قد تطرأ على

الحوار فتؤثر فيه تأثيرًا سلبيًّا، فينبغي مراعاة ذلك حتى يهقق الحوار غاياته ويؤتي ثمراته(اr). وأهم

$$
\text { هذه الآداب: }
$$

$$
\text { أولًا : تهيئة الجو المناسب للحوار }
$$

فلا بد من الابتعاد عن الأجواء الجماعية والغوغائية، لأن الحق قد يضيع في مثل هذه

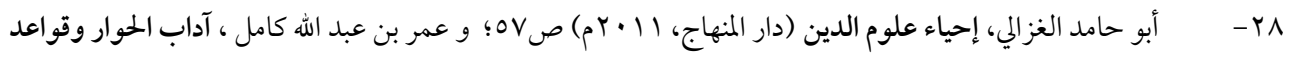

$$
\begin{aligned}
& \text { الاختلاف، ج اص0. } \\
& \text { 9 }
\end{aligned}
$$

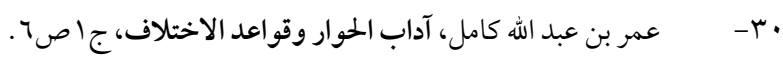

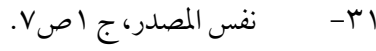




$$
\begin{aligned}
& \text { الأجواء. كما ينبغي اختيار المكان الهادئ وإتاحة الزمن الكافي للحوار. } \\
& \text { كما ينبغي مراعاة الظرف النفسي والاجتحاعي للطرف الآخر، فلا يصلح أبدًا أن يتم الحوار } \\
& \text { مع شخص يعاني من الإرهاق الجسدي أو النفسي، لأن هذه الأمور ستؤثر في الحوار. } \\
& \text { ومن الوسائل في تهيئة الجو المناسب للحوار: } \\
& 1 \text { - التعارف بين الطرفين. } \\
& \text { r - طرح أسئلة في غير موضوع الحوار لتهيئة نفسية الطرف الآخر. } \\
& \text { r - التقديم للحو ار بكلم|ت مناسبة ومقدمات لطيفة تلفت انتباه الطرف الآخر (rr). } \\
& \text { ثانيًا: الإخلاص وصدق النية }
\end{aligned}
$$

لا بد من توفر الإخلاص لله وحسن النية وسلامة القصد في الحوار والمناظرة، وأن يبتعد

المناظر عن قصد الرياء والسمعة، والظهور على الخصم والتفوق على الآخرين، والانتصار للنفس،

$$
\text { وانتزاع الإعجاب و الثناء. }
$$

ومن دلائل الإخلاص لله والتجرد لطلب الحق أن يفرح المحاور إذا ظهر الصواب على

لسان غخالفه، كما قال الشافعي: "ما ناظرت أحدًا إلا تمنيت لو أن الله أظهر الحتق على لسانه". ويعينه على ذلك أن يستيقن أن الآراء والأفكار ومسالك الحت ليست ملكًا لواحد أو

$$
\begin{aligned}
& \text { طائفة، والصواب ليس حكرًا على واحد بعينه(rr). } \\
& \text { ثالثًا: الإنصاف و العدل }
\end{aligned}
$$

من المبادئ الأساسية في الحوار: العدل والإنصاف من تمام الإنصاف قبول الحق من الخصم، والتفريق بين الفكرة وقائلها، وأن يبدي المحاور إعجابه بالأفكار الصحيحة والأدلة الجيدة،

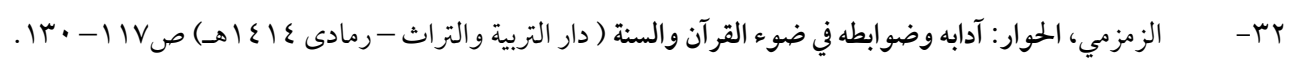

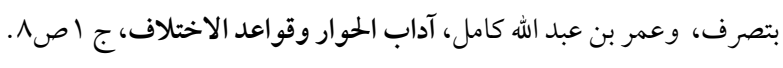

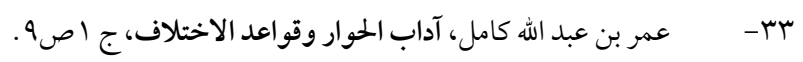




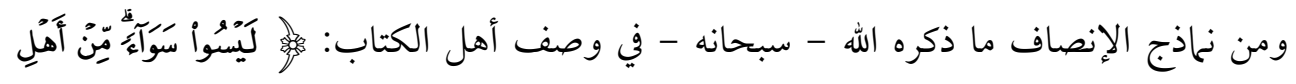

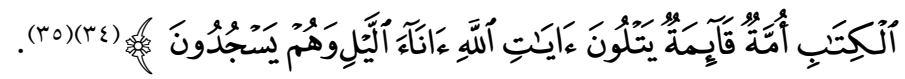
رابعًا: التواضع وحسن الخلق

إن التزام الأدب وحسن الخلق عمومًا، والتواضع على وجه الخصوص له دور كبير في إقناع الطرف الآخر، وقبوله للحق وإذعانه للصواب، فكل من يرى من محاوره توقيرًا وتو اضعًا،

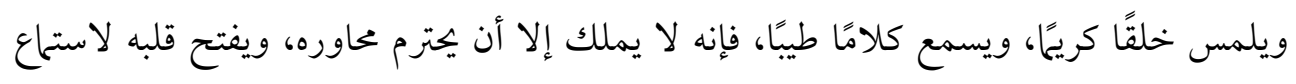

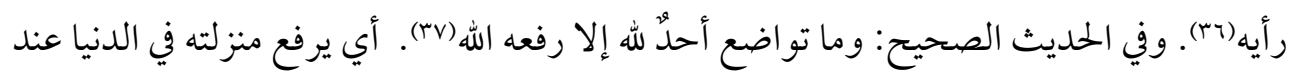

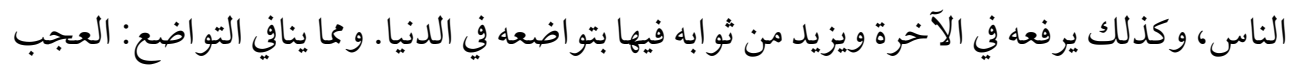

$$
\text { خامسًا: الحلم والصبر والكبر. }
$$

يجب على المحاور أن يكون حليمًا صبورًا، لا يغضب لأتفه سبب، ولا ينفر لأدنى أمر.

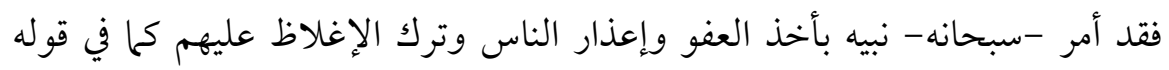

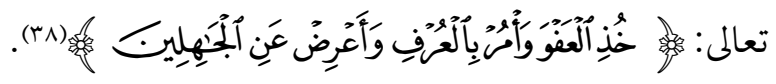

والصفح والعفو أبلغ من كظم الغيظ ورد الغضب، لأن العفو ترك المؤاخذة، وطهارة القلب، والسماحة عن المسيء، ومغفرة خطيئه. وأعظم من ذلك وأكبر هو دفع السيئة بالحسنة، ومقابلة فحش الكلام بلينه، والشدة

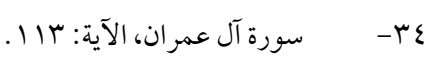

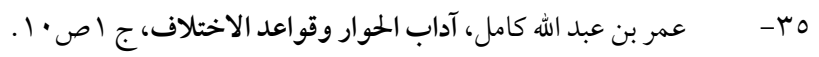

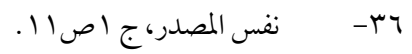

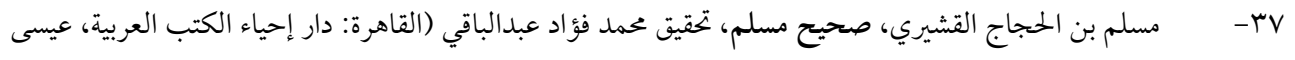

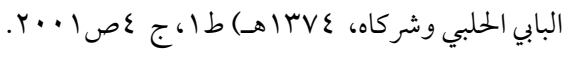

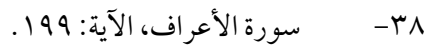


بالرفق، ورد الكلمة الجارحة بالكلمة الطيبة العذبة، والسخرية والاحتقار بالتوقير والاحترام وهذه

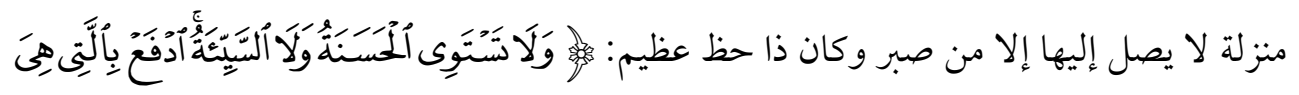

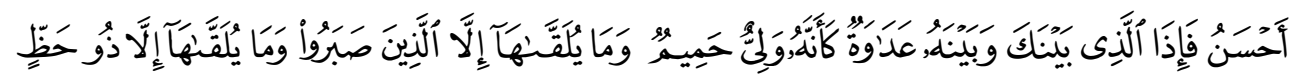

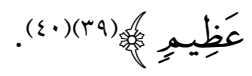

$$
\begin{aligned}
& \text { سادسًا: الرحمة والشفقة }
\end{aligned}
$$

إن المحاور المسلم المخلص الصادق يحرص على ظهور الحق، ويشفق على خصمه الذي

$$
\text { يناظره من الضلال، ويخاف عليه من الإعر اض و المكابرة والتولي عن الحق. }
$$

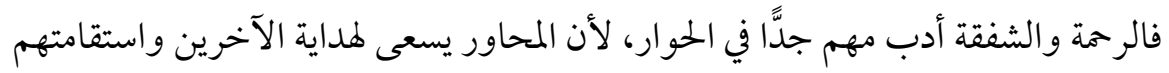
فلذلك يبتعد عن كل معاني القسوة والغلظة والفظاظة والشدة. فلا يكون الحوار فرصة للكيد والانتقام، أو وسيلة لتنفيس الأحقاد، وطريقة لإظهار الغل والحسد، ونشر العداوة والبغضاء. والرحمة جسر بين المحاور والطرف الآخر، ومفتاح لقلبه وعقله، وكلما اتضحت معالم الرحمة على المحاور انشرح صدر الخصم، واقترب من محاوره، وأذعن له واقتنع بكلامه. يقول -

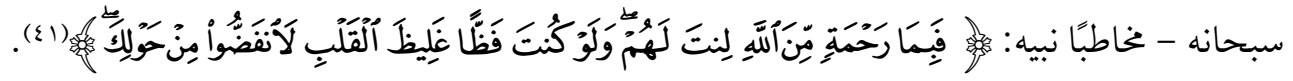

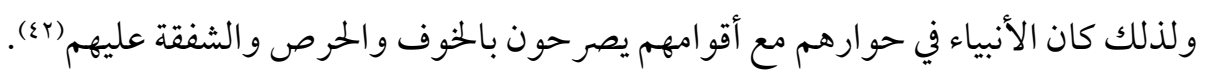

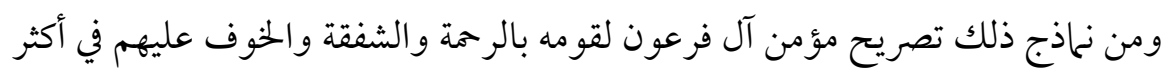

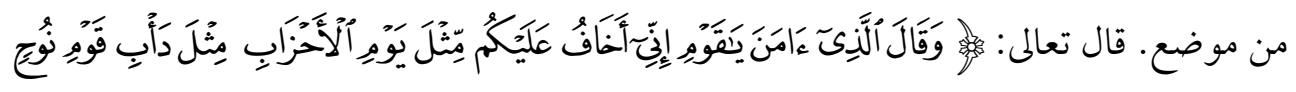

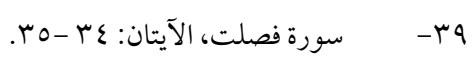

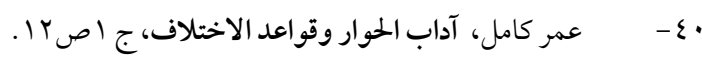

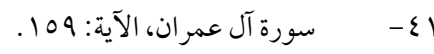

$$
\begin{aligned}
& \text { r }
\end{aligned}
$$




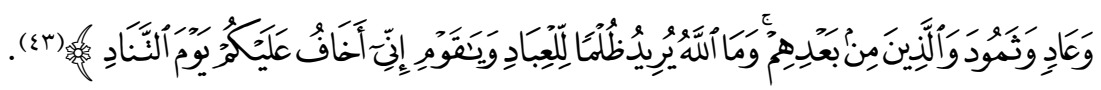

$$
\text { سابعًا: العزة والثبات على الحقق }
$$

إن المحاور المسلم يستمد قوته من قوة الدين، وعظمة الإيالن، فلا يجوز أن يؤدي الحوار

بالمسلم إلى الذلة والمهانة، والعزة الإيهانية ليست عنادًا يستكبر على الحقى، وليست طغيانًا وبغيًا، وإنما هي خضوع لله وخشوع، وخشية وتقوى، ومر اقبة لله سبحانه (ع ).

$$
\text { ثامنًا: حسن الاستحاع }
$$

لابد للمحاور الناجح أن يتقن فن الاستحاع فكما أن للكلام فنًّا وأدبًا، فكذلك للاستحاع

وليس الحوار من حق طرف واحد يستأثر فيه بالكلام دون محاوره، ففرق بين الحوار الذي فيه تبادل

$$
\text { الآراء وبين الاستحاع إلى خطبة أو محاضرة. }
$$

ومما ينافي حسن الاستماع: مقاطعة كلام الطرف الآخر، فإنه طريق سريع لتنفير الخصم

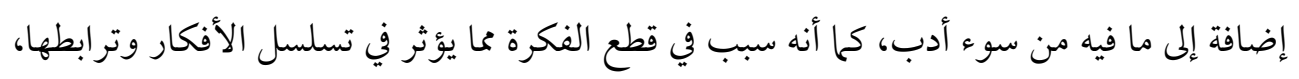

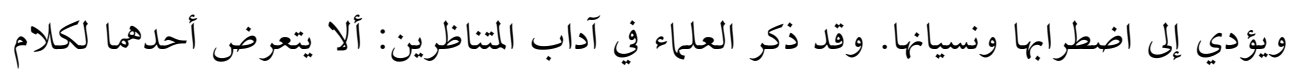

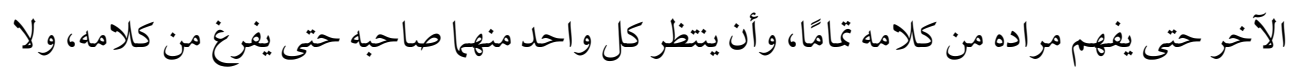

$$
\text { يقطع عليه كلامه من قبل أن يتمه. }
$$

والاستحاع إلى الطرف الآخر وحسن الإنصات، تهيئ الطرف الآخر لقبول الحق، وتمهد

$$
\begin{aligned}
& \text { نفسه للرجوع عن الخطأ(ع) ). } \\
& \text { تاسعًا: الاحترام والمحبة على رغم الخلاف }
\end{aligned}
$$

الخلاف أمرٌ واقع لا عحالة ولكن لا يهوز أن يؤدي الخلاف بين المتناظرين الصادقين في

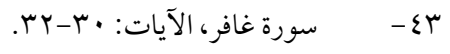

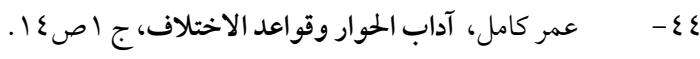

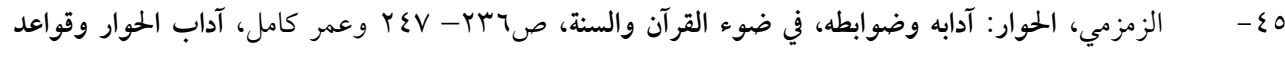

rr 


$$
\text { طلب الحق إلى تباغض وتقاطع وتهاجر أو تشاحن وتدابر. }
$$

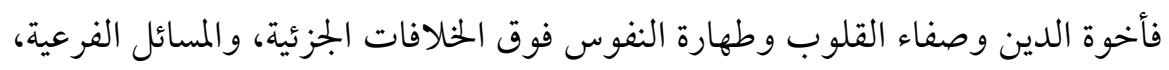

واختلاف وجهات النظر، لا ينبغي أن يقطع حبال المودة، ومهها طالت المناظرة، أو تكرر الحوار فلا

$$
\text { ينبغي أن تؤثر في القلوب أو تكدر الخواطر أو تثير الضغائن. }
$$

لقد اختلف السلف فيها يينهم وبقيت بينهم روابط الأخوة الدينية.

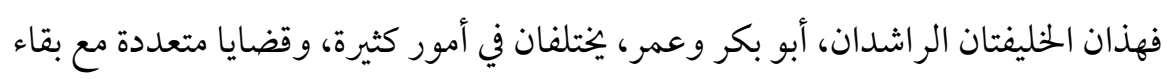

$$
\text { الألفة والمحبة، ودوام الأخوة والمودة. }
$$

ومع هذا الخلاف بينها إلا أن كل واحد منها كان يحمل الحب والتقدير والاحترام للآخر،

$$
\text { ويظهر ذلك من ثناء كل واحد منها على صاحبه (i乞). }
$$

المبحث الثاني: الحوار في ضوء القرآن الكريم والسنة النبوية المطهرة، ويشتمل على مطلبين

$$
\text { المطلب الأول: الحوار في ضوء القرآن الكريم }
$$

الحوار في الإسلام يقترب من الفرائض، لأن القرآن الكريم يريد التقارب بين البشر

بصورة عامة، ولا يكون التقارب إلا بالحوار الحسن، ولذلك يتطلب تبني الحوار داخل الجلماعة

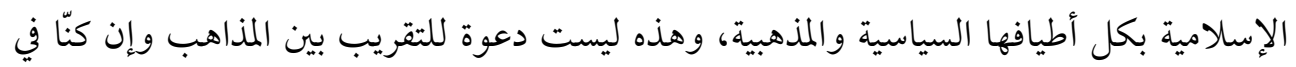
حاجة إليها، ولكن الحوار يجب أن يقوم على فلسفة واضحة تنطلق من النواة الأولى، أي الحوار داخل الجماعة الواحدة ، ومن السذاجة أن ننطلق للحوار مع الآخر ونحن نعجز عن الحوار مع

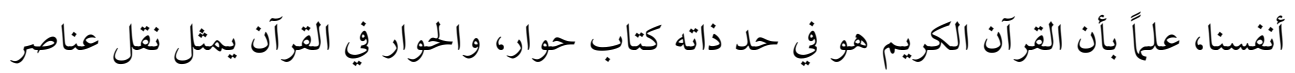
الفكر الإنساني بكل خصائصه الثقافية والشعورية للإنسان الآخر الذي يقوم بالدور نفسه بالنسبة

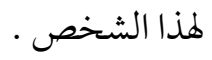

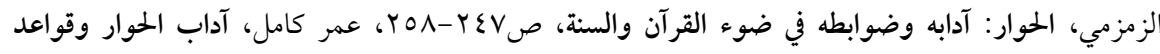


إن الحوار الأول في القرآن الكريم كان حواراً بين اله والملائكة عندما قال لهم: .

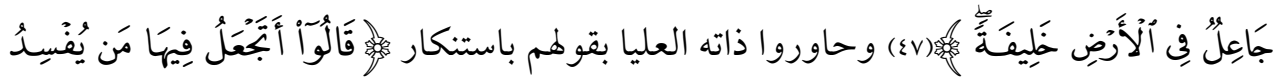

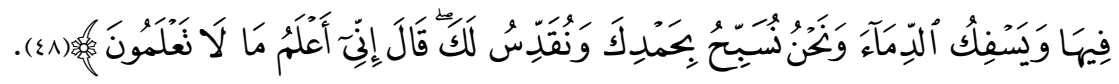
وانتهى الحوار باقتناعهم عندما أخبرهم آدم عليه السلام بالأسماء

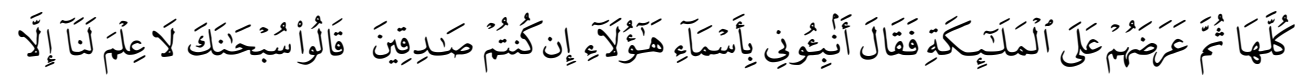

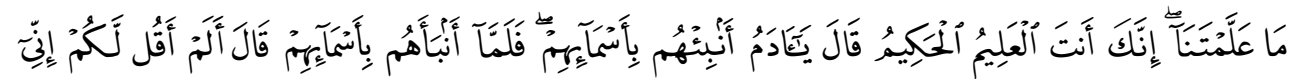

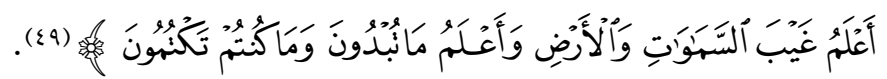

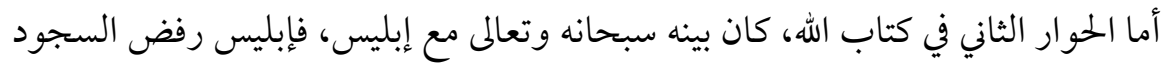
لآدم، لكنه لم يرفض فرصة الحوار مع الله سبحانه(0)، وعبر إبليس عما في نفسه، وقدم طلبه إلى الله

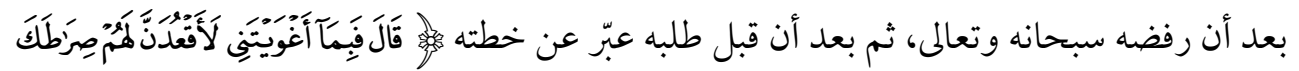

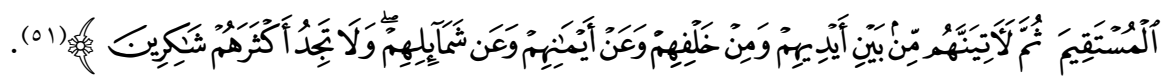

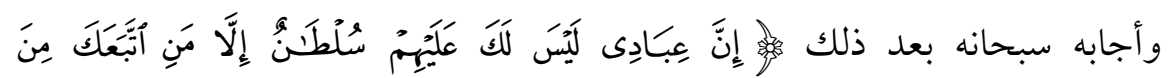

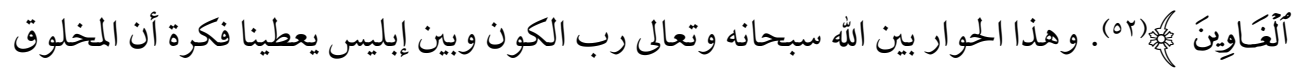

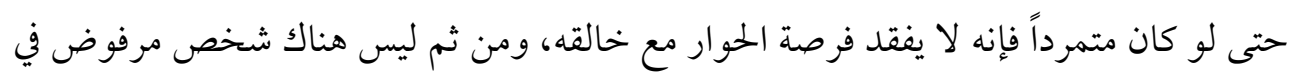

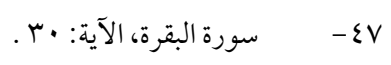

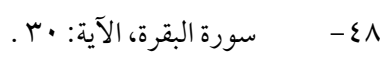

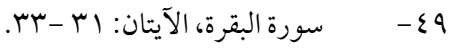

$$
\begin{aligned}
& \text { 0 - م - م السيد محمد حسين فضل الله، مستقبل الحوار الإسلامي (بيروت : الإسلامي - كتاب الكلمة -- منتدى الكلمة - }
\end{aligned}
$$

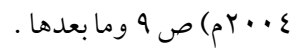

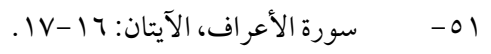

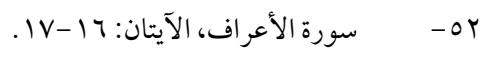

ro 
الحوار، وبالإمكان محاورة أي إنسان مها كانت درجة سقوطه الإنساني والديني والاجتماعي .

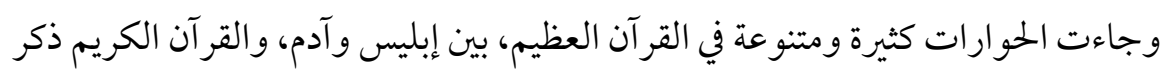
حوارات متعددة بين المؤمنين والكافرين والشاكين والمنافقين، ثم حوارات بين هذه الطوائف المختلفة، بحيث يمكن القول إن الحوار هو الوسيلة لتأكيد المعرفة وتحريك الواقع، وطلب القرآن الكريم أن يدخل الإنسان في حوار مع نفسه. وقد وضع الله في قرآنه الكريم قو اعد ثقافية ومعرفية للحوار ييب أن يأخذ بها المتحاور في

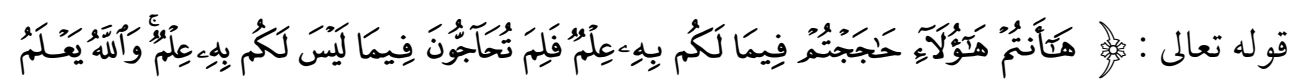

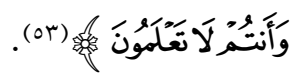

فأراد اله للإنسان المحاور أن يملك المعرفة فيا يحاور فيه، وأراد للحوار أن ينطلق من خلال أصول موضوعية تحترم إنسانية الإنسان المحاور سواء في مقام الدعوة أو في مقام الخصام

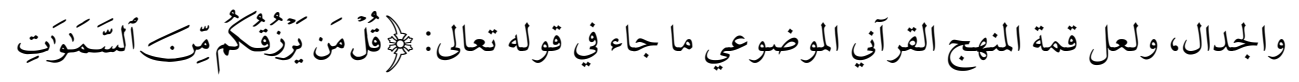

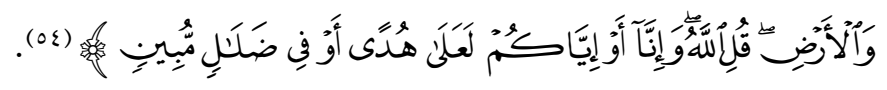

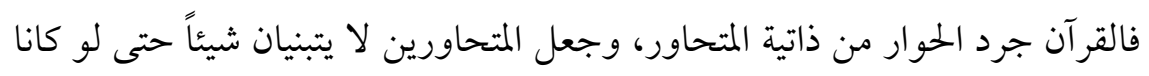

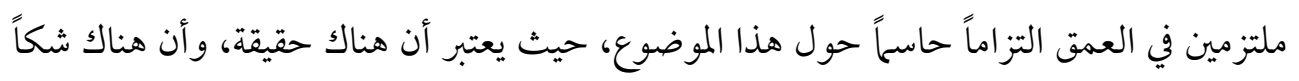
مشتركاً وأن الطرفين يريدان أن يحركا الشك في طريق اليقين حتى يلتقيا بالحقيقة، ويعتبر هذا لها

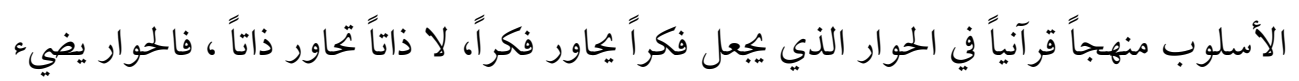
للإنسان مواطن الحقيقة (00). وييعل الإنسان يكتشف الآخر دون اللجوء للإكراه فضاه فضلاً عن القتل

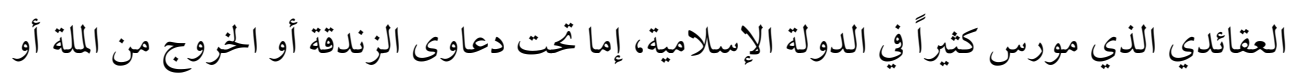

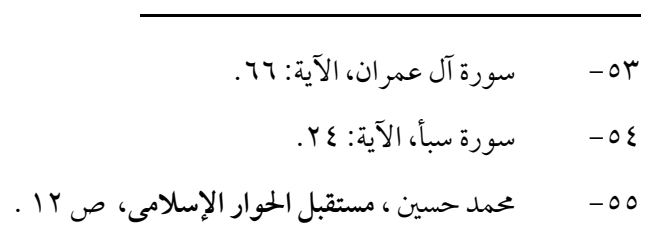


مفارقة الجماعة، وجميعها سياسية غطت برداء الدين كثيراً، وفي الحقيقة كانت هناك محاولات كثيرة جابه العلماء فيها الخلفاء، ولكنها ظلت مواجهات فردية للعلماء لم تأخذ صفة الجماعية هذا باستثناء

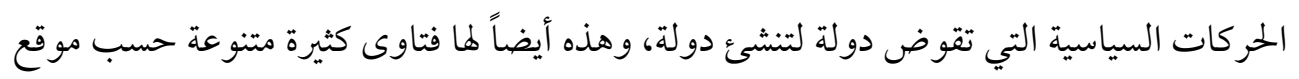

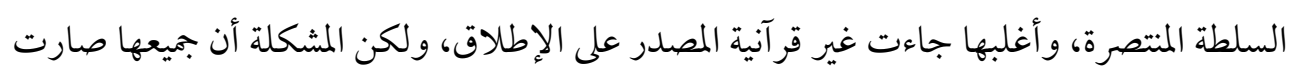

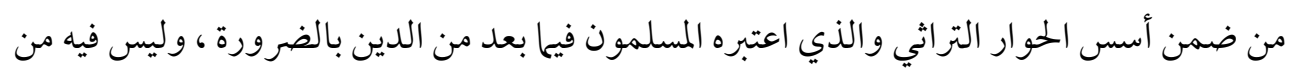
الضرورة شيء، ولسنا بصدد الدخول في التاريخ لكل فترات التاريخ الإسلامي؛ ولكنا نريد إيضاح الحقيقة، كما جاءت في القرآن على لسان النبي صلى اله عليه وسلم. ونورد هنا حوارا حدث بين النبي صلى اله عليه وسلم وبين المشركين، صاغه القرآن

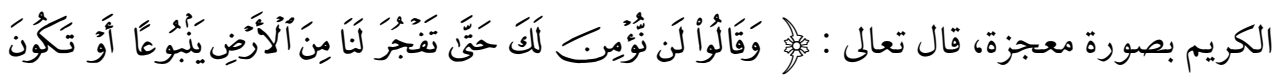

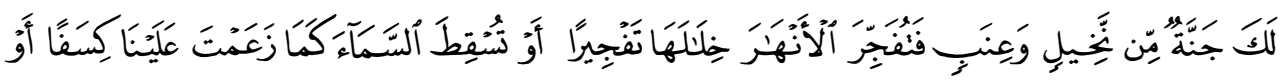

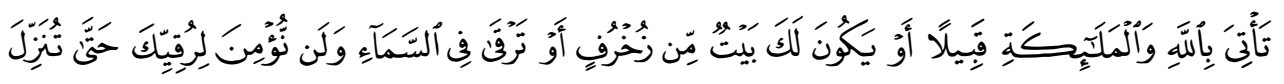

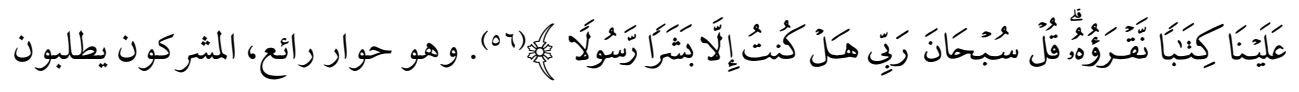
طلبا يريدون من ورائه إعجاز النبي عليه الصلاة والسلام، يطلبون منه الينبوع من الأرض فره الصحراوية، وطلبوا نزول الملائكة، وطلبوا كتابا يرونه نازلا من السماء، ولم يكن رد النبي عليهم سوى سبحان ربي، ما أنا إلا بشر رسول، وفي هذا الحوار القصير يمكن التنبؤ بكل الحوارات

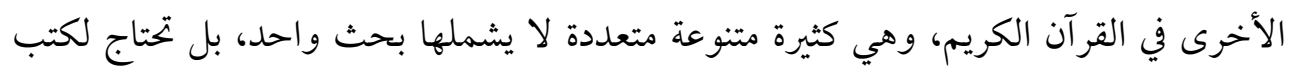

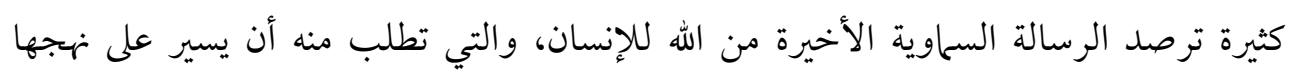
الحواري.

إن الإنسان في تصور القرآن مخلوق أرضي حقاً، ولكنه بحكم تكوينه ووظيفته موصول 
بالسماء(ov)، وبهذه الصفة يجب أن يقدم له خطاب ديني متحرر من أي قيود غير قرآية كما رأيناها

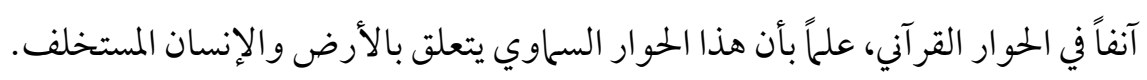

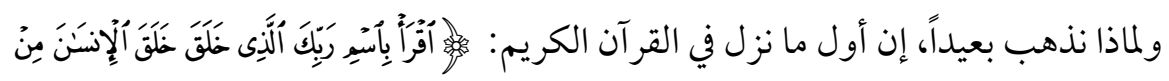

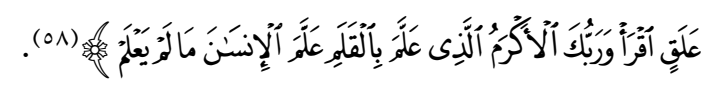

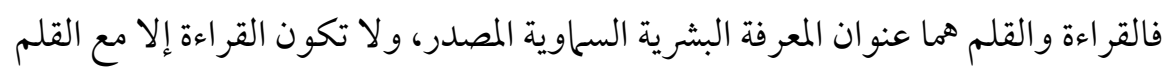

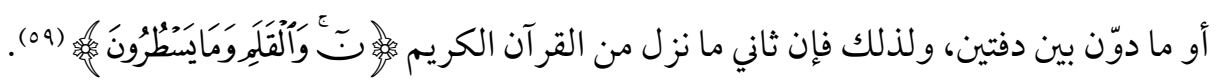

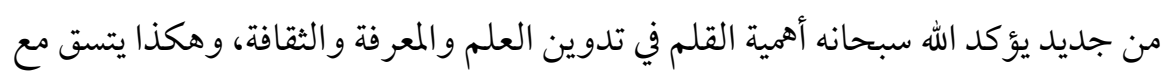

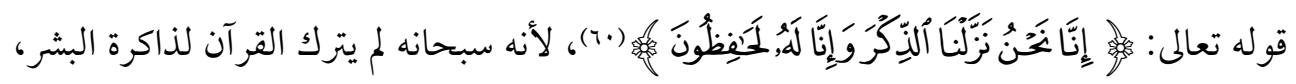

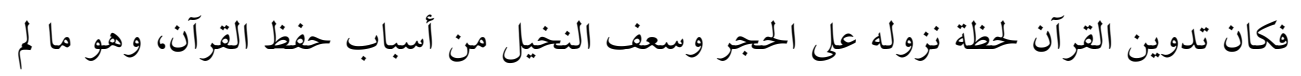
يحدث للكتب السابقة التي لم تدون في حينها فضاع كثير من معالمها، والخطاب الديني التراثي لم الم

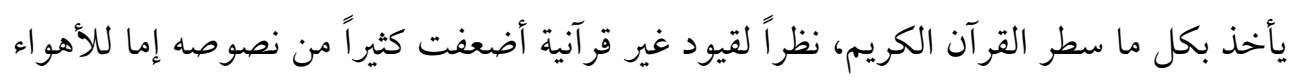

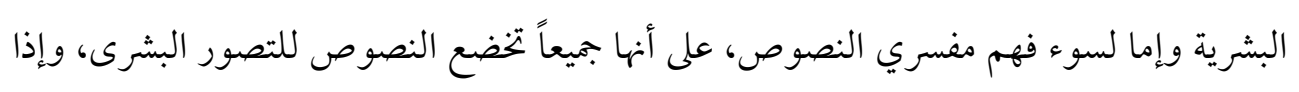

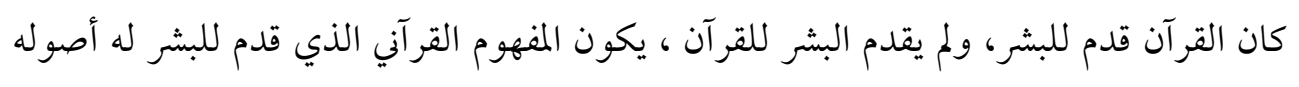

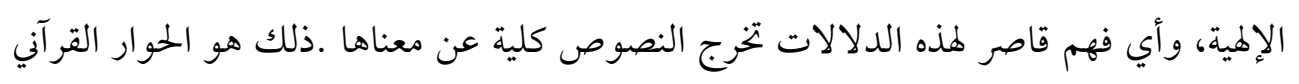

$$
\text { الإلهي المصدر المحمدي التطبيق. }
$$

وعندما نعود للأصل القرآني نجد أن الحوار الممكن لابد أن يكون أولا بين المسلمين

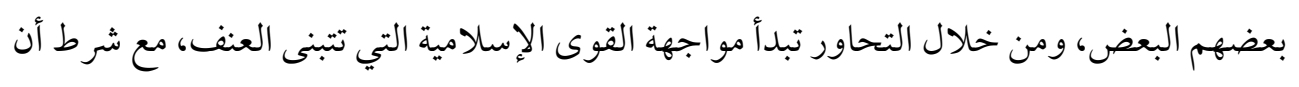

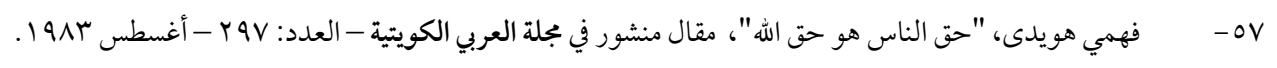

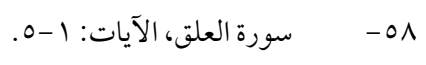

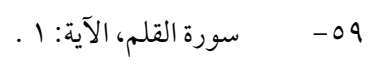

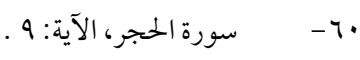


يشمل الحوار كل نقاط الاختلاف، وكل زوايا الخلاف والخلافات، لتكون الأرضية المشتركة بين الجميع. وذلك من أجل عدم التفريط بالقيم والمثل العليا الإسلامية، وعدم السماح للآخرين باختراقات جديدة لتلك القيم الراسخة في نفوس الملايين، ومن أجل صياغة ثقافة إسلامية حية

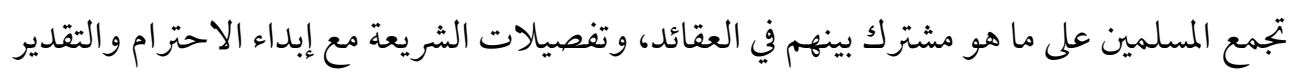

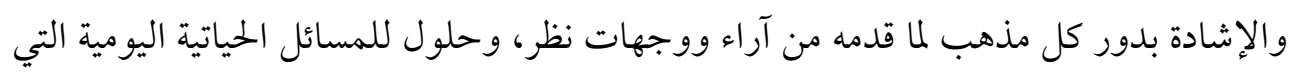
يبتلى بها المسلمون واغناء للفكر الإسلامي، وباعتبار الاختلاف عامل قوة وتنوع للشريعة الإسلامية بوجود أكثر من رأي مطروح حيال أي مسألة شرعية أو معضلة دينية، يستطيع المسلم الأخذ بأحد الحلول التي تناسبه ضمن الضوابط الشرعية.

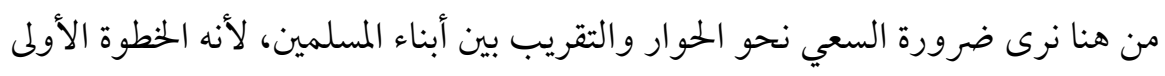
في التمسك بالأمل(17)، كل ذلك من حوار إسلامي أولا وقبل كل شيء، فالحوار هو الذي يقود

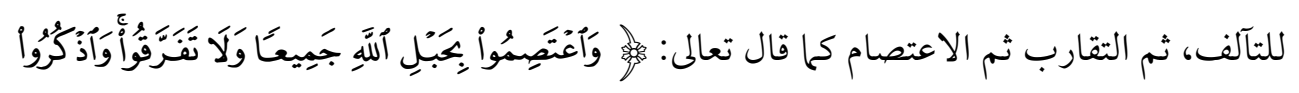

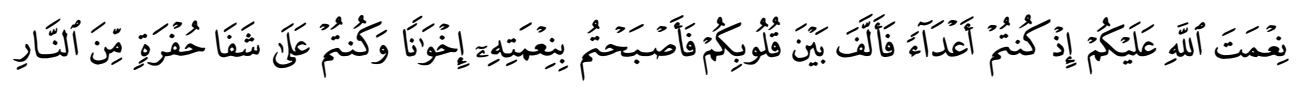

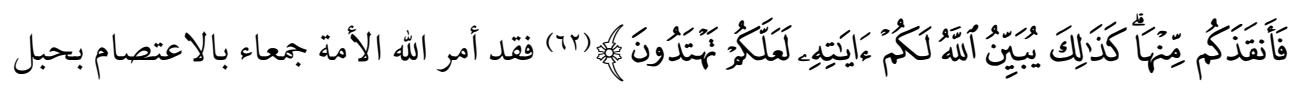

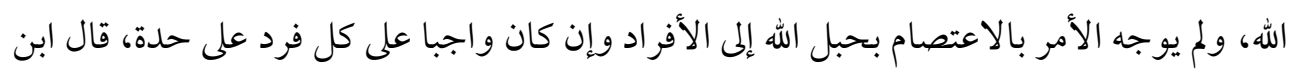

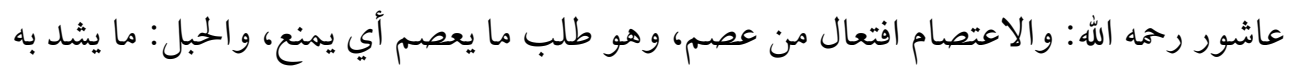

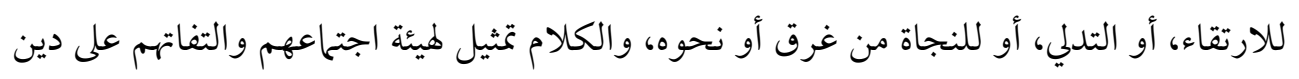

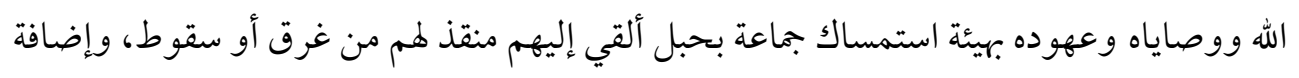

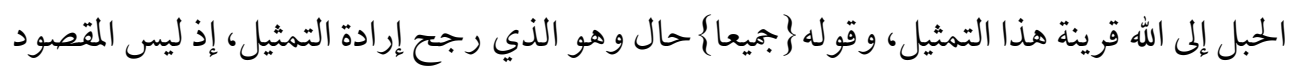

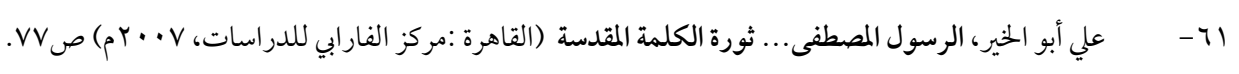

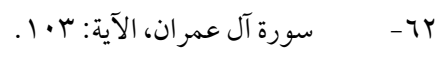


الأمر باعتصام كل مسلم في حال انفراده اعتصاما بهذا الدين، بل المقصود الأمر باعتصام الأمة كلها (Tr).

هذا جزء من الحوار كما مثله القرآن الكريم نكتفي به لأن فيه الكفاية، والحوار في القرآن يجتاج إلى أبحاث. المطلب الثاني: الحوار في السنة النبوية المطهرة حفلت نصوص القرآن ومواقف السنة النبوية بها يدلُّ على أن الإسلام يُوْْثرُ دائما السلام(18)، ومن أدلَّة ذلك أنَّ القرآن الكريم أو رد كلمة "السلم" بمشتقاتها مائة وأربعين مرَّة، في حين ذُكِرَت كلمة "الحرب" بمشتقاتها ست مرات فقط (10)، والفرق بين العددين هو الفرق بهر

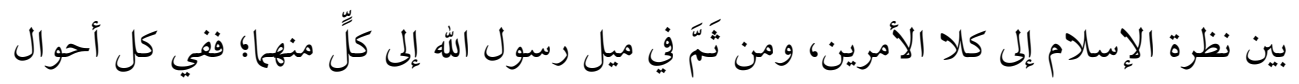
رسول الله، كان يبحث عن الطرق السلمية والهادئة للتعامل مع المخالفين له عبر الحوار معهم،

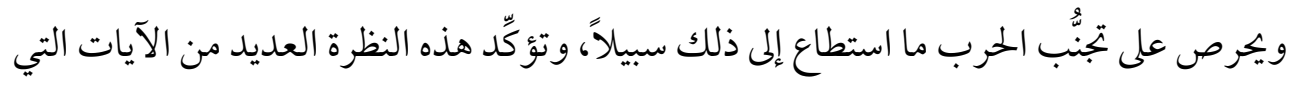
أمرت بالسَّلْم مع غير المسلمين إن أبدى هؤلاء الاستعداد والميل للصلح والسلام؟ فيقول الله

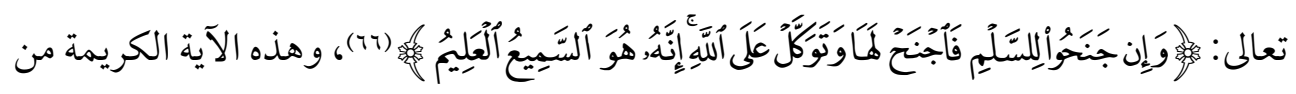
كتاب الهه تبرهن بشكل قاطع على حُبِّ المسلمين وإيثارهم للسلم متى مال الأعداء إليه، مالم لم يكن من وراء هذا الأمر ضياع حقوقِ للمسلمين أو سلب لإرادتهم، لذلك يقول الشيخ محمود شلتوت شيخ الجامع الأزهر الراحل : "إن السلم هو الحالة الأصلية التي تهيِّئ للتعاون والتعارف وإشاعة الخير بين الناس عامَّة، وإذا احتفظ غير المسلمين بحالة السلم، فهم

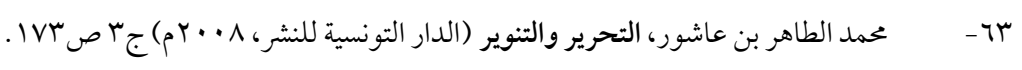

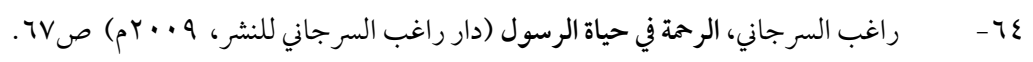

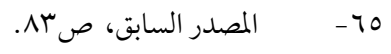

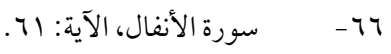


والمسلمون في نظر الإسلام إخوان في الإنسانية"(TV)، ولهذا كله كان رسول الله صلى الله عليه وسلم يعتبر السلام من الأمور التي على المسلم أن يحرص عليها ويسأل الله أن يرزقه إياها.

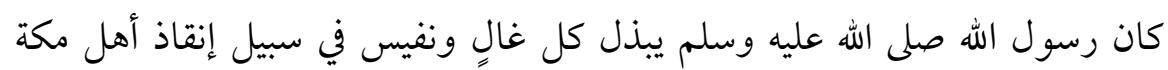
وإخراجهم من الظلمات إلى النور، رغم عنادهم وقسوتهم في التعامل معه ومع من أسلم من ونس

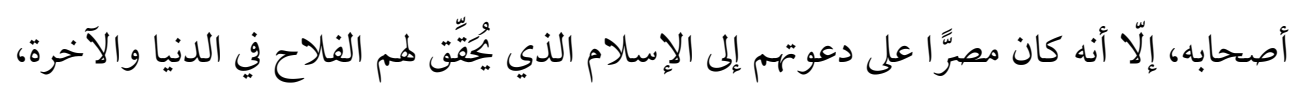
ويتمثل ذلك في دعائه لهم بالهداية، وكذلك اتسم بسمة التبشي؛؛ فحياة رسول الله من من أقوال

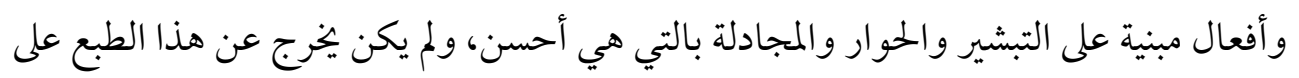
الرغم من قسوة المشركين عليه، فعن ربيعة بن عباد الديلي -وكان جاهليَّا ثم أسلم- قال:

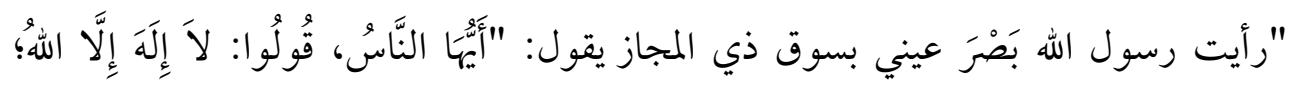
تُفْلِحُوا..."(1)، هو يريد إسلام القوم من خلال الاقتناع الذاتي العقلي وبالتأمل في الخلق والمخلوقات، في التدبر في السماء، وطلب من الإنسان أن يدخل حوارا مع نفسه من خلال التأمل و التعقل و الفهم. وهذا ما طبقه النبي صلى الله عليه وسلم في كل حياته الشريفة، كان يتلو القرآن الكريم

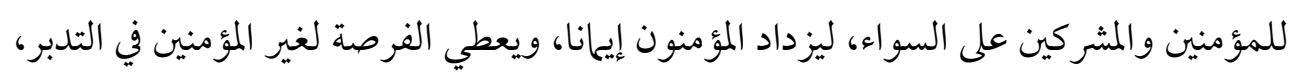

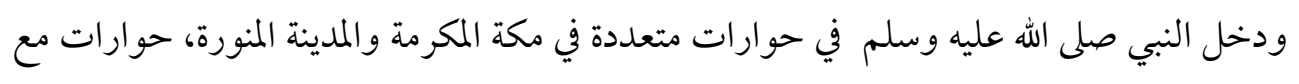
المسلمين و المشركين.

ومنها: الحوار النبوي في مكة المكرمة في مكة المكرمة بعد بدء البعثة النبوية، قام النبي صلى الله عليه وسلم بالدعوة إلى الله تعالى،

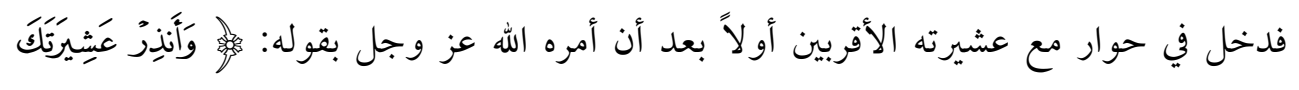

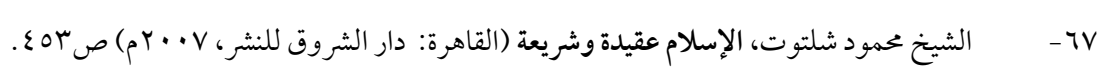

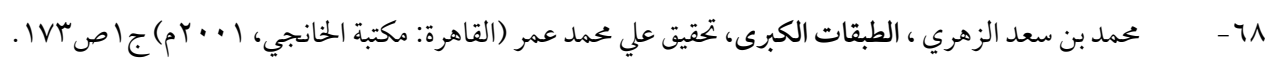

r) 


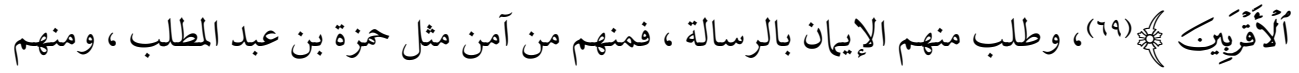

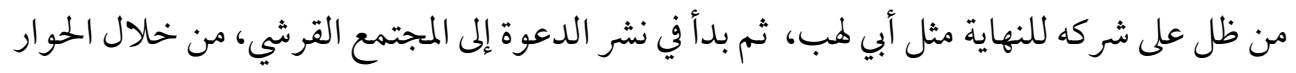
الهادئ الموضوعي، ونقتصر هنا على نموذجين حواريين من النبي عليه أفضل الصلاة و التسليم.

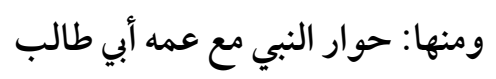
كان أبو طالب عم النبي هو الذي رباه وحماه عندما انطلق بدعوته الإلهية، ودائم) كانت قريش تحاول منع أبي طالب من حماية الرسول صلى الله عليه وسلم ، ولما أكثرت قريش الكلام والنقد لأبي طالب، جاء وفد من قريش إليه وطلبوا منه أن يوقف النبي عن النيل من آلهتهم الوثنية، قال ابن إسحاق: "حدثني يعقوب بن عتبة بن المغيرة أنه حدث: أن قريشا حين قالوا لأبي

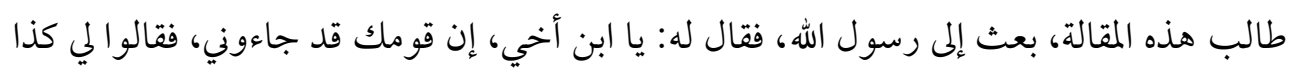

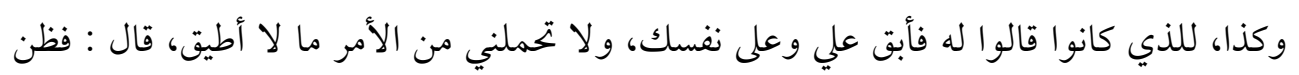

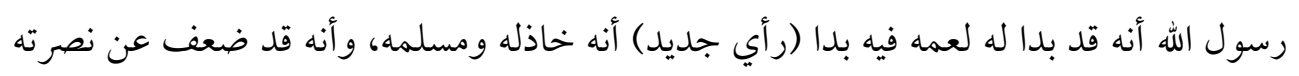

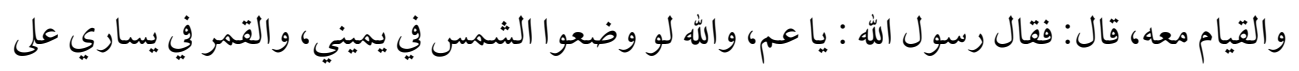

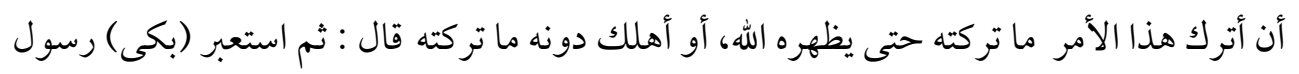
الله ، ثم قام، فلما ولى ناداه أبو طالب، فقال : أقبل يا ابن أخي، قال: فأقبل عليه رسول الله ، فقدال:

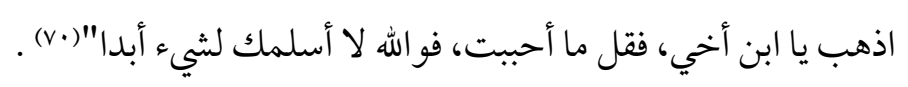

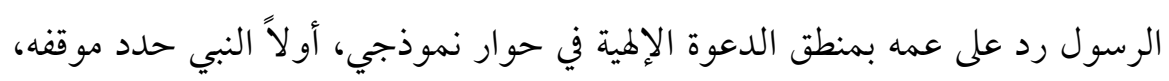

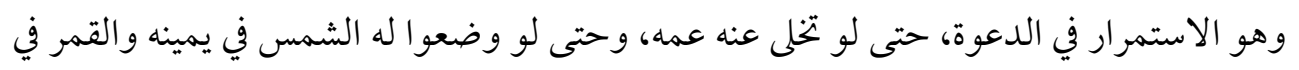
يساره، وهنا جاء الحوار باستمر ار وقوف أبي طالب معه.

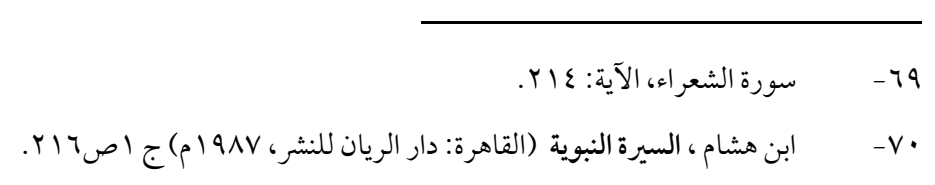




$$
\text { ومنها: حوار النبي مع زعيم قرشي }
$$

في نموذج حواري آخر، كان مع زعيم عظيم من زعماء قريش، وهو عتبي متبه بن ربيعة، يروي

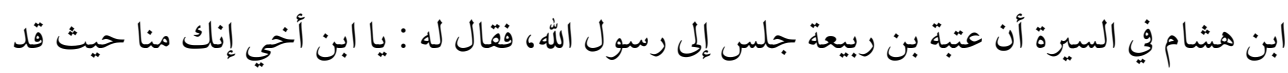

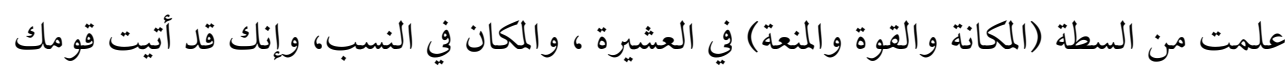

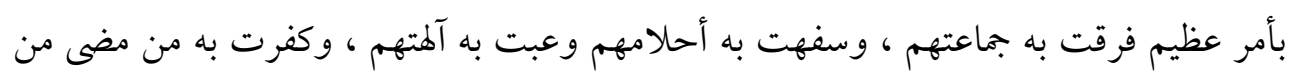

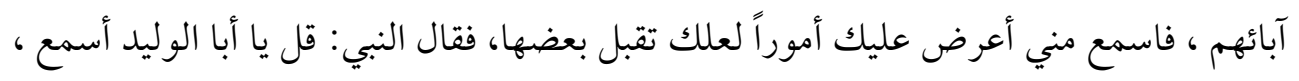

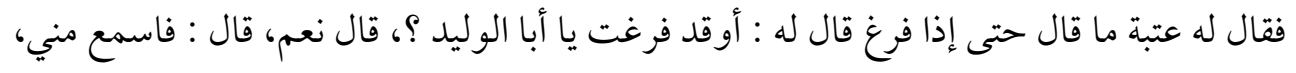
قال : أفعل، فأخذ الرسول يتلو عليه من سورة فصلت ، حتى انتهى إلى الآية موضع السجدة منها

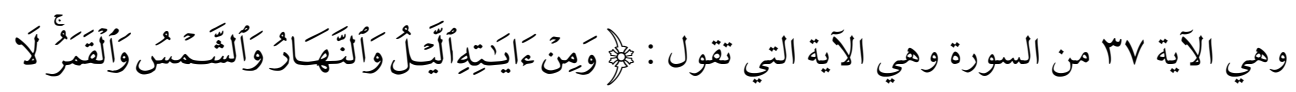

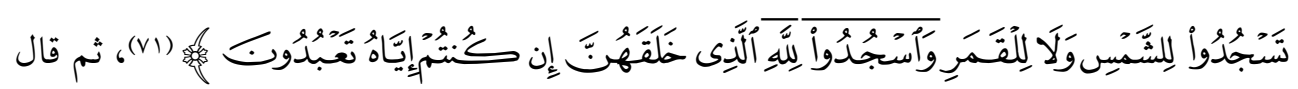

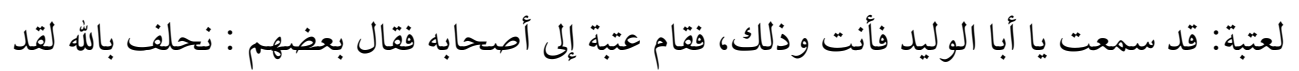
جاءكم أبو الوليد بوجه غير الوجه الذي ذهب به، وطلب عتبة إليهم أن يدعوا الرسول صلى الله

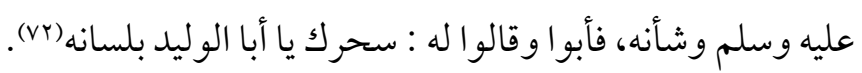
في هذا الحوار نجد أن عتبة بن ربيعة يعود مأخوذا بالقرآن، بل يطلب منهم ترك النبي

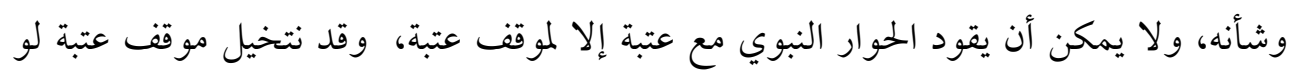

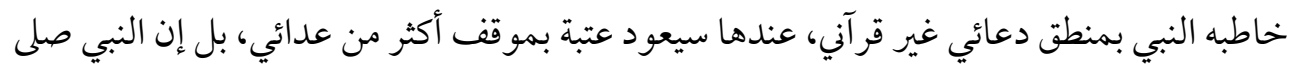

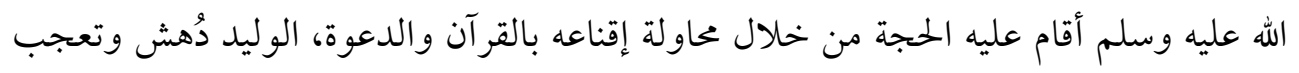
بالقر آن ولكنه لم يسلم، وكبره هو الذي منعه، ثم قتله المسلمون يوم معركة بدر الكبرى.

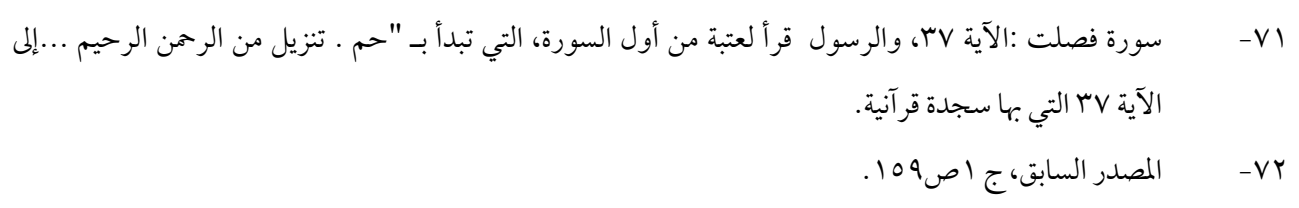

ru 
وتروي كتب التاريخ أنّ الوليد بن المغيرة ، الّذي يصفه العرب بريحانتهم وحكيمهم سمع

الآيات التالية من النبي صلى الله عليه وسلم

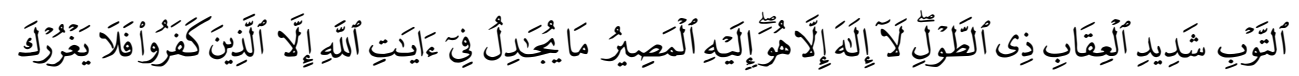

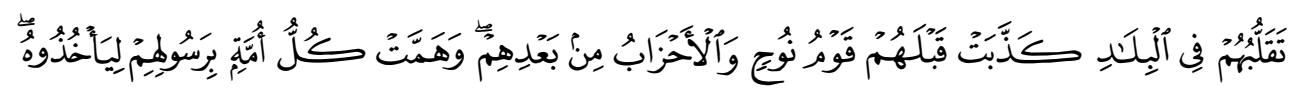

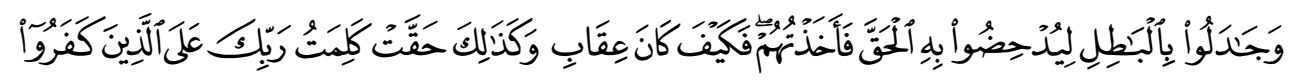

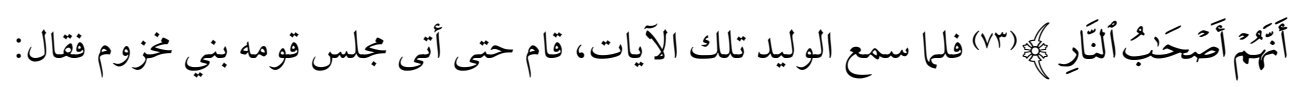

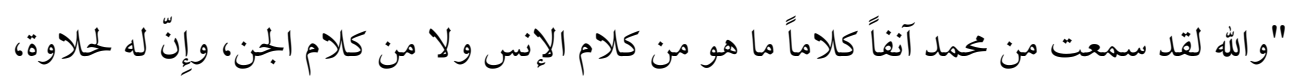

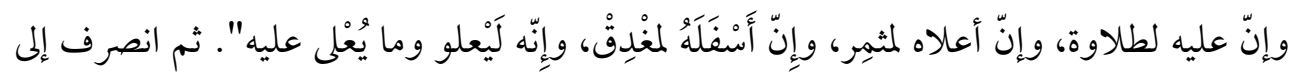

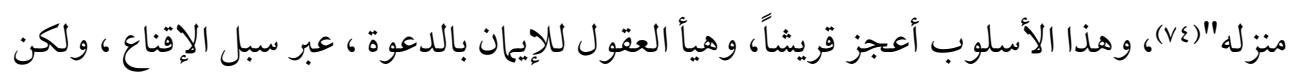

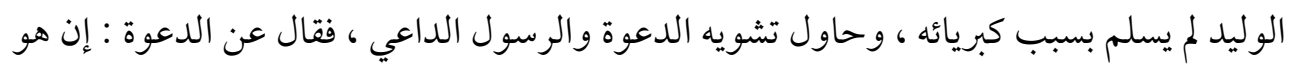

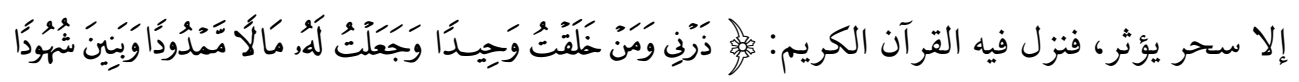

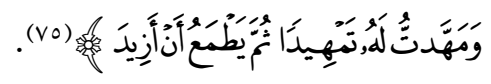

$$
\begin{aligned}
& \text { ومنها: حوار النبي عند فتح مكة }
\end{aligned}
$$

عندما فتح النبي عليه الصلاة والسلام مكّة، ترك أهلها المشركين وشأنهم، ولم يكونوا أهل

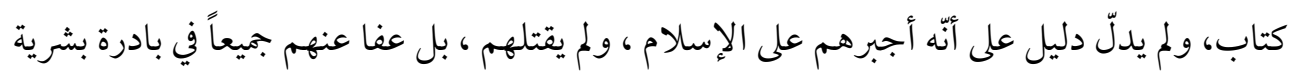

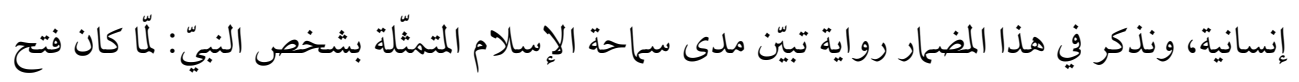

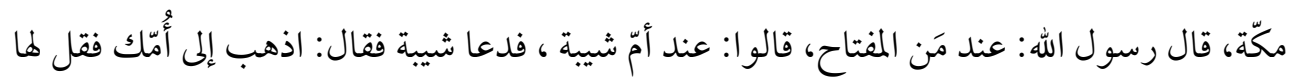

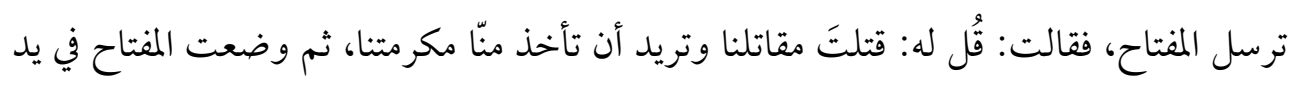

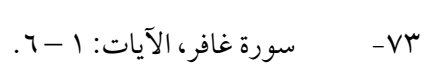

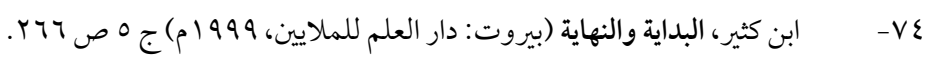

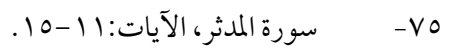


الغلام، فأخذه النبي، وقال له: هذا تأويل رؤياي من قبل. ثمَّ قام النبي فقتحه وستره، فِمِن يومئذ

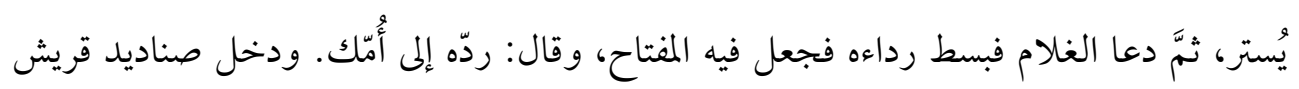
الكعبة وهم يظنّون أنّ السيف لا يُرْفع عنهم ، فأتى رسول الله البيت وأخذ بعضادَّيَ الباب، ثمَّ قال:

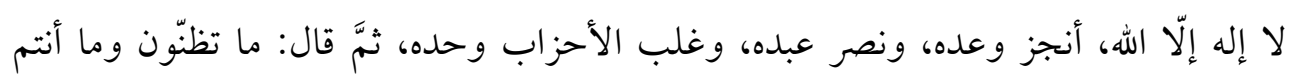

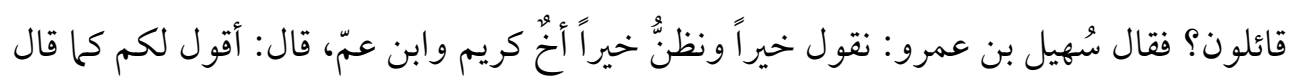

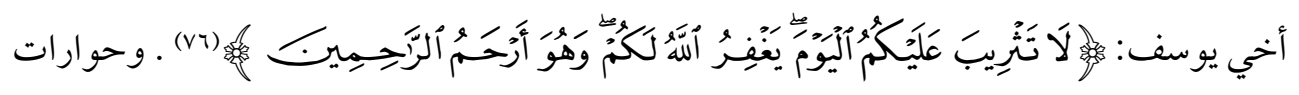
النبي صلى الله عليه وسلم في مكة اكثر من ان يحصيها بحث ولكن ماذكرناه فيه الكفاية.

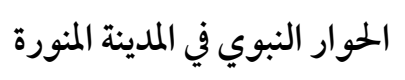

بعد أن هاجر النبي صلى الله عليه وسلم من مكة إلى المدينة المنورة، وجد جماعة من اليهود،

فدخل معطم في حوار مكتوب ضمن صحيفة المدينة: فقد جاء في الصحيفة "هذا كتاب من محمد

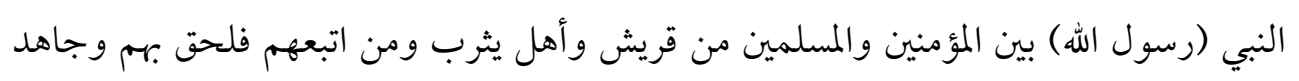

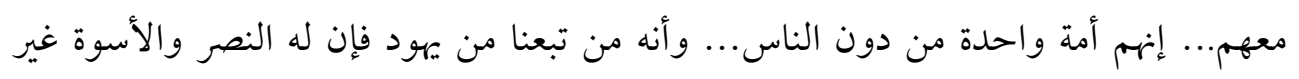

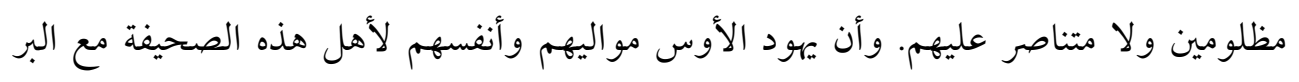

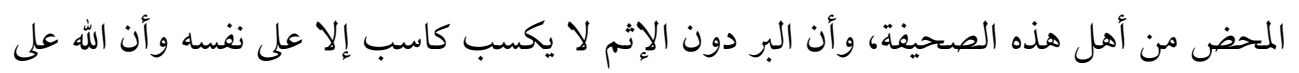

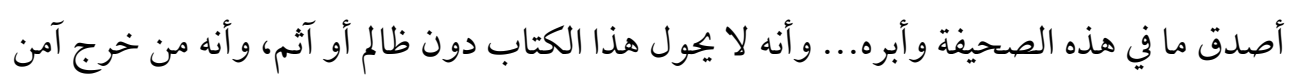

$$
\begin{aligned}
& \text { ومن قعد آمن بالمدينة إلا من ظلم أو أثم، وأن الله جار لمن بر واتقى...."vv). } \\
& \text { وتعتبر صحيفة المدينة أول وثيقة حقوقية إنسانية في تاريخ البشرية. }
\end{aligned}
$$

ودخل النبي الكريم من خلال القرآن الكريم في حوارات مستمرة مع اليهود والنصارى لئه

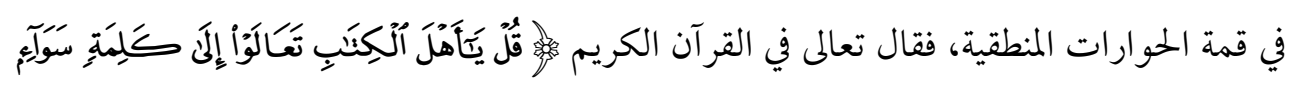

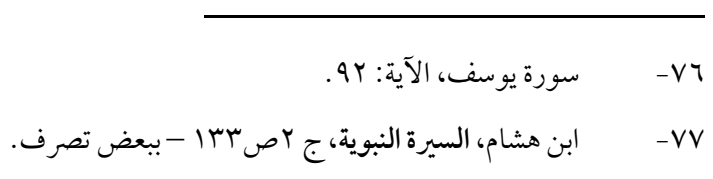

ro 


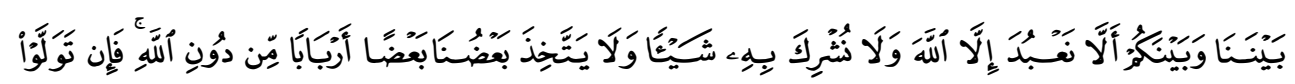

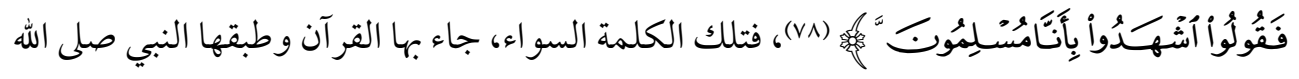

$$
\text { ومنها: حوار النبي مع المنافقين }
$$

تعامل النبّي عليه الصّلاة والسّلام مع المنافقين في المدينة تعاملًا عبّر عن عقليّة فذّة تمتلك الكن

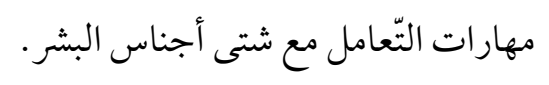

فقد تزعٌم عبد الله بن أبي سلول سدّة النّفاق في المدينة، حيث وصلته أخبار يوماً عن

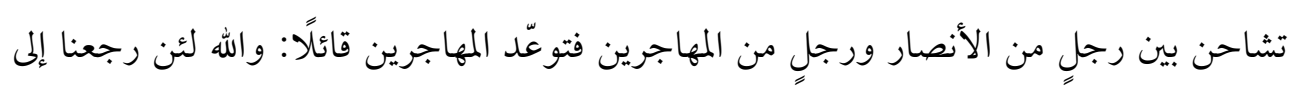

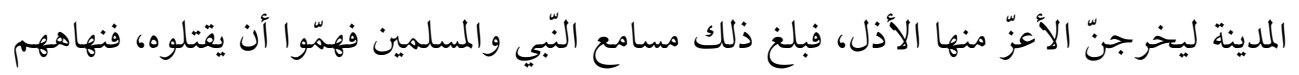

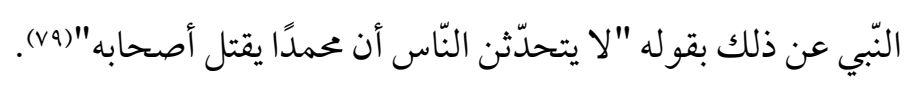

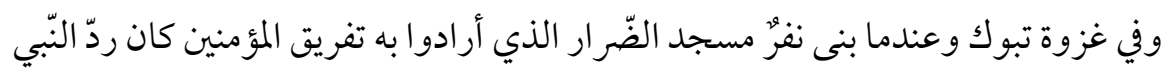

عليه الصّلاة والسلام حازمًا لخطورة الموقف حيث أمر بهدم المسجد على أساساته، كما اتخّذ النّبي الكريم أسلوب الوعظ والتّذكير مع المسلمين حينما بثّ المنافقون بينهم دعاوي الجاهليّة، فقال يومًا

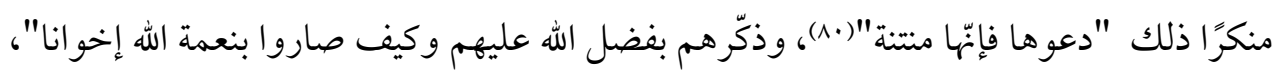

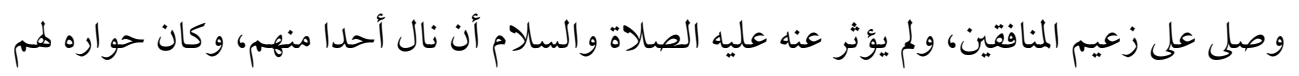
مقدمة لإخلاص كل المسلمين له، وصل الأمر بهذا الإخلاص أن طلب ابنه عبد الله بن عبد الله بن

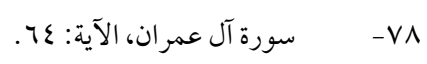

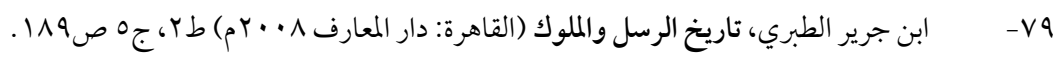

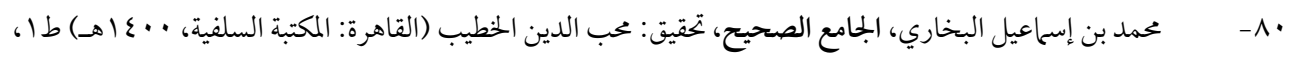

$$
\begin{aligned}
& \text { ه.9ء، مسلم بن الحجاج القشيري، صحيح مسلم ، تحقيق محمد فؤاد عبدالباقي (القاهرة: دار إحياء الكتب }
\end{aligned}
$$

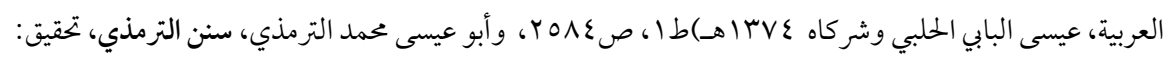

$$
\begin{aligned}
& \text { أحمد بن محمد شاكر (بيروت: دار الكتب العلمية، بدون تاريخ ) } 10
\end{aligned}
$$


أبي بن سلول أن يقتل أباه، ولكن النبي رفض، وقال له: " نحسن صحبته "(11) العدل النبوي

لا يتحقق الحوار العادل الإيجابي سوى تطبيق العدل، والعدل بعد التوحيد مباشرة،

ولذلك نجد أن رسول الله كان حريصا على تعليم أصحابه قيمة العدل مبيّنًا لهم عظيم أجره فقال عليه السلام: "إن المقسطينَ في الدنيا على منابر من لؤلوِ يومَ القيامة بين يدي الرحمن بها أقسطو افي

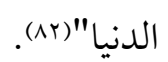

والعدل من الأخلاق النبويّة والشمائل المحمديّة التي اتّصف بها رسول الله صلى الله عليه

وسلم، عدلّ وسِعَ القريب والبعيد، والصديق والعدو، والمؤمن والكافر، عدلّ يزن بالحقّ ويقيم القسط ، عدل وصل إلى درجة أن يطلب من الآخرين أن يقتصّوا منه صلوات الله وسلامه عليه خشية أن يكون قد لحقهم حيفُ أو أذى منه، وهو أبلغ ما يكون من صور العدل (r^). ومن المو اقف النبوية التي تبين مدى حرصه صلى الله عليه وسلم على العدل، موقفه مع الصحابي سواد بن غزية رضي الله عنه في غزوة بدر، قال ابن إسحاق: "حدثني حبان بن واسع بن حبان عن أشياخ من قومه: كان النبي يسوي بين الصفوف في الصلاة، فطعن في بطنه بالقدح، وقال: استوِ يا سواد، فقال: يا رسول الله، أوجعتني، وقد بعثك الله بالحت والعدل، قال: فأقدني(اقتص لي من نفسك)، فكشف رسول الله صلى الله عليه وسلم عن بطنه، وقال: استقِد، قال: فاعتنقه فقبل بطنه، فقال: ما حملك على هذا يا سو اد؟!؛ قال: يا رسول الله، حضر ما ترى، فأردتُ أن يكون آخر العهد بك أن يمس جلدي جلدك، فدعا له رسول الله صلى الله عليه وسلم بخير"(^)، هنا حوار بين النبي وأحد أتباعه من الصحابة، الصحابي يطلب العدل في الحوار، والعدل هو

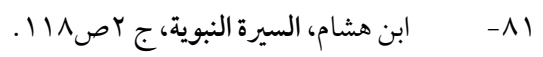

$$
\begin{aligned}
& \text { r }
\end{aligned}
$$

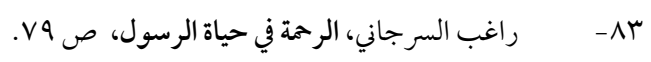

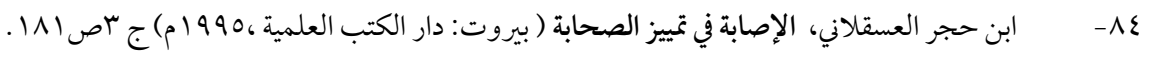


القصاص من النبي، والنبي في الحوار العادل لم يرفض، بل كشف عن نفسه للقصاص، ثم تبين أن

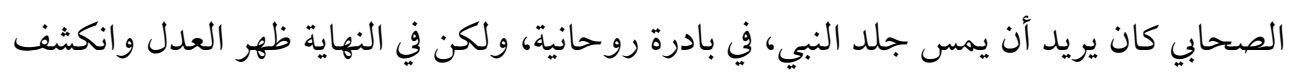

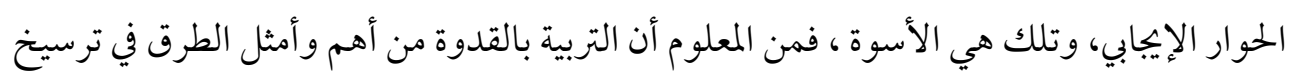
المبادئ والقيم، وهي طريقة النبي صلى اله عليه وسلم، فالقيم والأخلاق والقواعن التد التربوية في

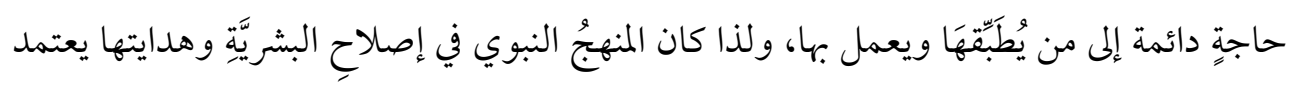

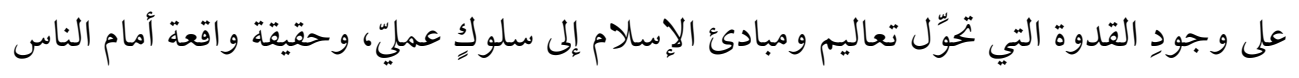

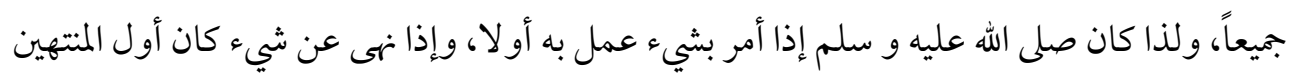
عنه".

قال ابن حجر في كتابه الإصابة حين عرّف بالصحابي الجلندى ملك عمان: " أن رسول الله صلى الله عليه وسلم بعث إليه عمرو بن العاص يدعوه إلى الإسلام، قال الجلندى : "لقد دَلَّنِي

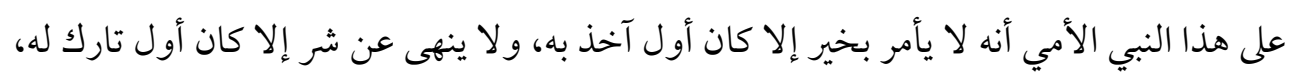

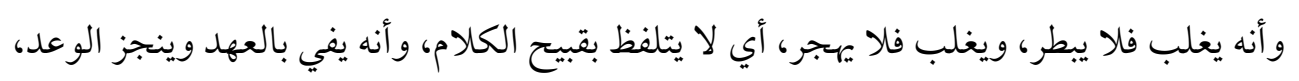
وأشهد أنه نبي"(10) ، وهي شهادة بمنطق العقل ومنطق الفهم دون ضغط أو إجبار أو أو إكراه ، وتؤكد للمسلم وغير المسلم صورة النبي والقرآن والدعوة بالحكمة والموعظة الحسنة. ومنها: رسائل النبي صلى الله عليه وسلم إلى الملوك لا يستقيم الحديث عن الحوارات النبوية دون التطرق إلى رسائله إلى الملوك في عصره

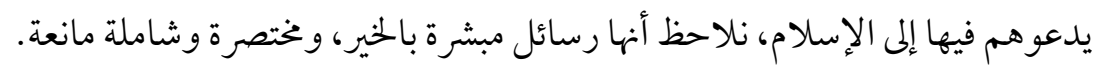

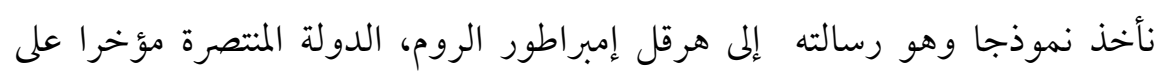

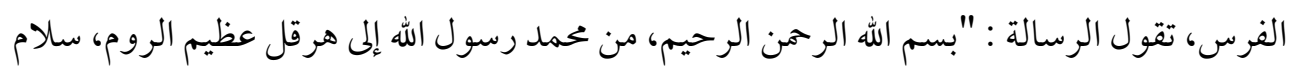

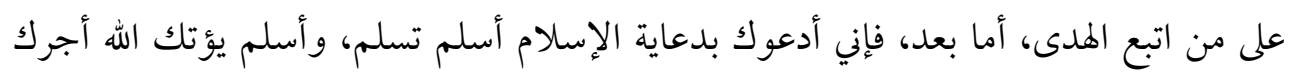


مرتين، وإن توليت فإن عليك إثم الأريسيين

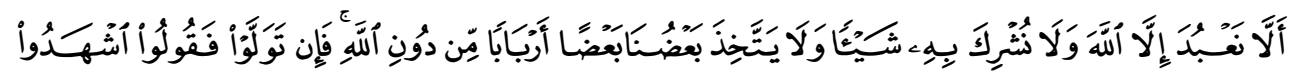

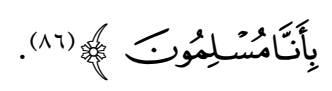

نلاحظ في الرسالة أن النبي صلى الله عليه وسلم بدأ رسالته بتوقير هرقل باعتباره عظيم

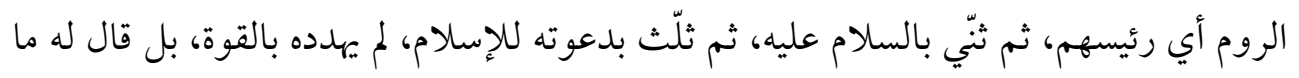

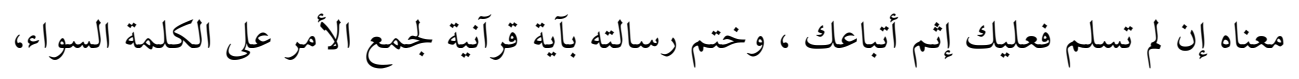

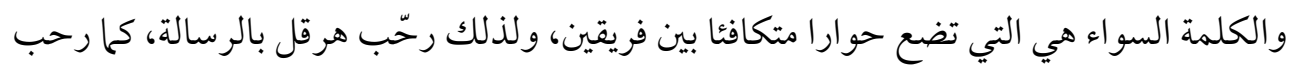

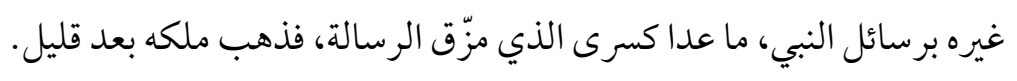
ومنها: وفد نصارى نجران جاء وفد من نصارى نجران لمقابلة النبي صلى الله عليه وسلم للتأكد من صدق دعوته،

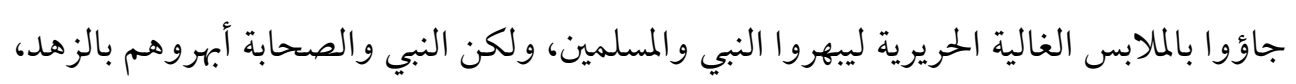

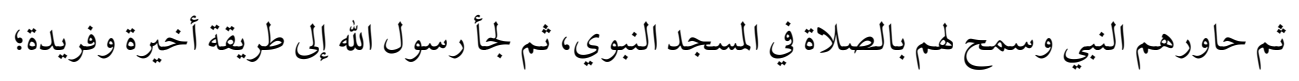

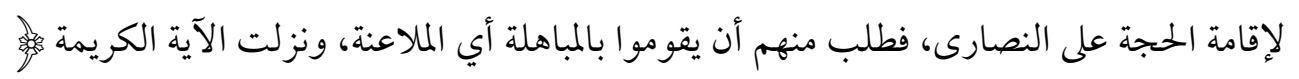

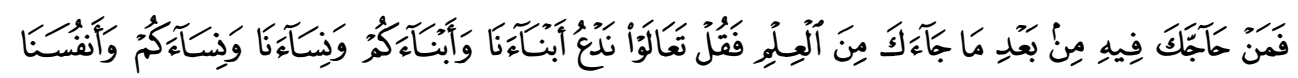

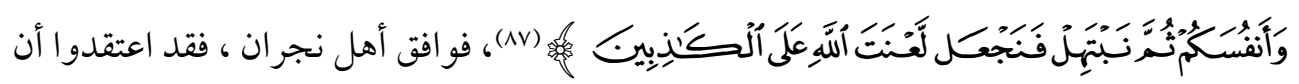

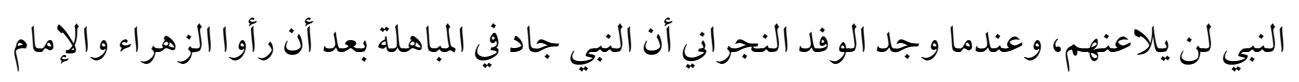

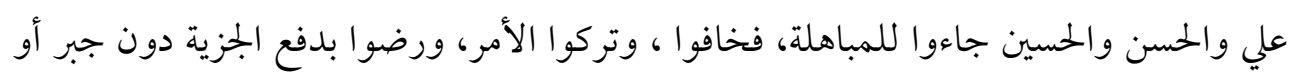
إكراه. تلك بعض حوارات النبي عليه الصلاة والسلام جاءت لتؤكد أن الحوار الأمثل هو

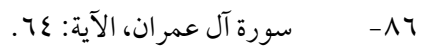

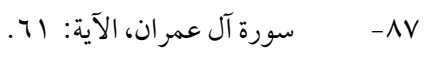




$$
\text { الطريق لنشر دعوة أو لإفشاء فكرة. }
$$

المبحث الثالث: كيفية تعامل الإسلام مع غير المسلمين وطرق تعزيز الحوار وتقويته في العصر

$$
\text { المطاضر عصر التقدم العلمي. ويشتمل على مطلبين: }
$$

بعد أن رأينا منطق القرآن الكريم في الحوار وكيف طبق النبي صلى الله عليه وسلم هذا

الحوار في التعامل مع الأعداء والصحابة، نكتب عن موقف الإسلام إذن من غير المسلمين، وهي القضية التي نراها لازمة ليدخل المسلمون في حوار مع بعضهم البعض، ومع غير المسلمين أيضا، لأن الإسلام جاء بقيم إنسانية مشتركه لا يمكن أن نجور عليها أو نتناساها، ونستند للقر آن والسنة الشريفة، ونكتب ليس من موقف الدفاع عن الإسلام بقدر ما هو توضيح للرؤية الإسلامية، فالغرب يهاجم الإسلام بأنه يضطهد الأقليات مثلا، أو أنه يرفض حقوق الإنسان، وكلها من

$$
\begin{aligned}
& \text { أدبيات غير محايدة، وغير منصفة. } \\
& \text { رؤية الإسلام للأقليات }
\end{aligned}
$$

للإسلام نظرة مغايـرة لمفهوم الأقلّية والأكثرية، فهو لا ينظر لبني الإنسان داخل

المجتمعات الإسلامية ، أنَّ هناك أقلّية و أكثرية مِن ناحية عددية أو دينية أو عِرقية ... إلخ ، بل المعيار الوحيد الذي يذكره ويطرحه ـ بشكل موسّع ـ للأقلّية والأكثرية ، هو معيار الحتّ والتقوى، فمَن يتبعه فهم الأقلية ، ومَن يضادّه هم الأكثرية، وليس هذين المصطلحَين مِن ذِكر إلّا في هذا

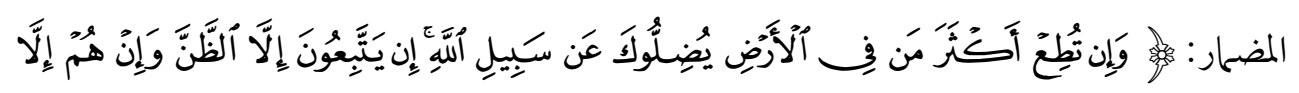

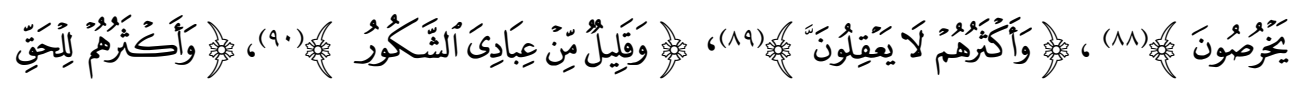

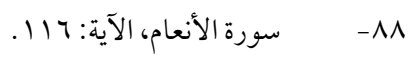

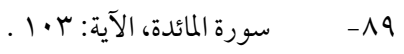

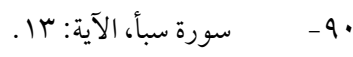




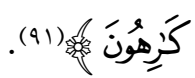

فالمسألة في نظر القرآن الكريم هي تحقّق العدالة للجميع، وإعطاؤهم كافّة حقوقهم بصورة متساوية، والفَرق الوحيد داخل المجتمع هو اتباع الحقّ وعدمه، وعليه فالإسلام لا يُفرِّق بين الناس مها كانت فوارقهم اللُّغَوية والدينية، ومها كانت عاداتهم وتقاليدهم، فكلّهم متساوون في الحقوق،

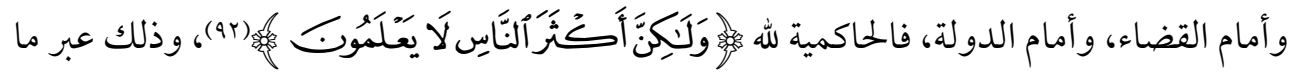
نزل في شريعةٍ مقدّسة وخاتمة لكلّ شر ائعه السابقة.

أمّا مصطلح الأقلّية الدينية المطروح في المجتمع الإسلامي اليوم، فهو مصطلح معاصر مو افقا مع ما طُرح مِن معاهدات ومواثيق دولية(9r)، فدخلت في موسوعة الثقافة الإسلامية حديثاً، و إلّا فالديانات الأخرى في المجتمع الإسلامي، هي ليست أقليّات حسب نظر الشرع الإسلامي، بل هم أهل ذّّة وعهُد، لهم أحكامهم وحقوقهم الكاملة طبقاً للشريعة المقدّسة، فلهم الحرّية الدينية في الالتزام بدياناتهم واعتقاداتهم ضمن شروط الذمّة. فلو لا هذه الشروط؛ لتصدّع المجتمع بكامله وعمَّته الفوضى، واختلَّ النظام الاجتماعي. هذا من الناحية الدينية (ع).

أمَّا مِن ناحية اللغة أو اللون، فلا أقليّة في الإسلام مِن هذه الجهة، قال تعالى: وَهِ وَمنْ

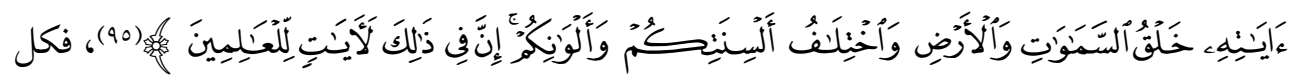
المجتمعات الإسلامية بشتّى لُغاتها وألو انها لا فرق فيها بينها في الشريعة المقدّسة بكلّ الحقوق والواجبات.

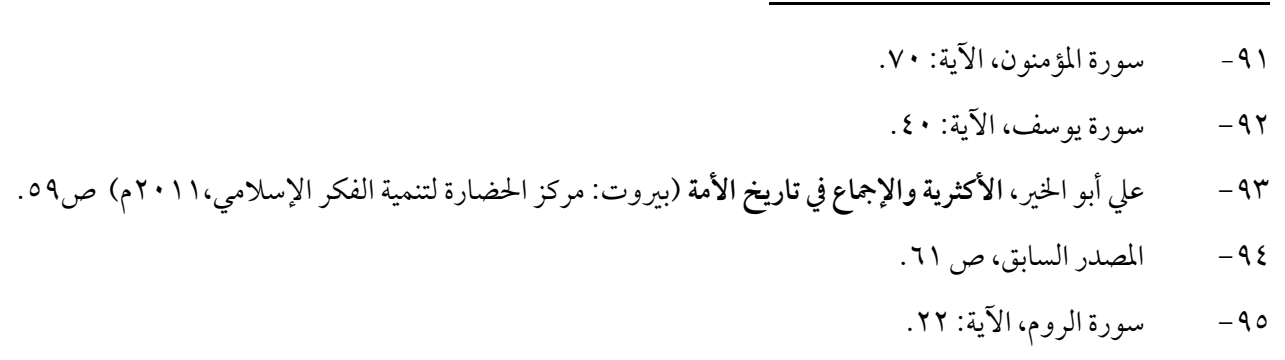




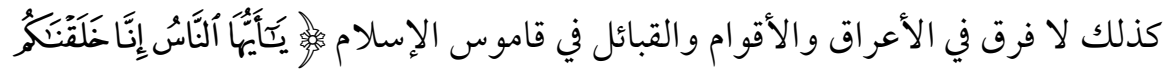

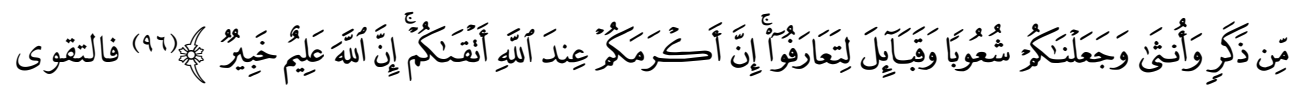

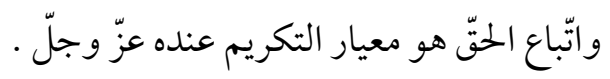

إذن فأصحاب الديانات الأخرى متساوون بالحقوق مع المسلمين، ولا يجوز عُ إيذاؤهم.

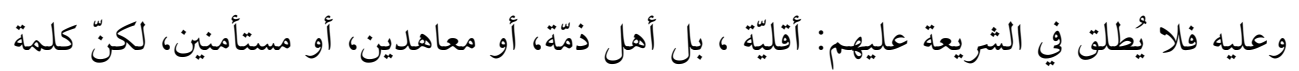
أقليّات دينية جاءت في الوقت الحاضر لتتناسب مع المعاهدات والمو اثيق الدولية.

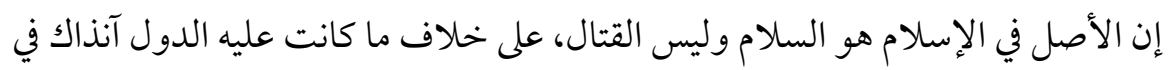

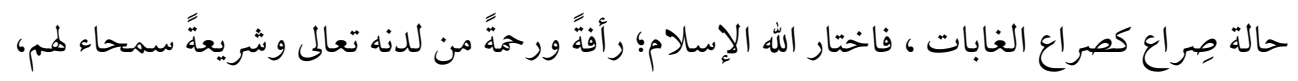

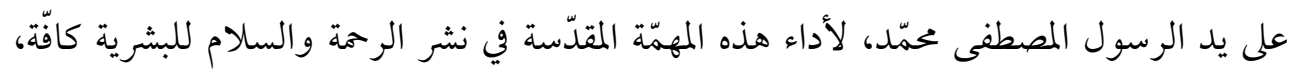

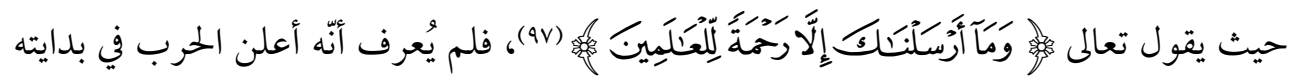
المبار كة وظلّ انتشاره إلّاّ ما شرّ عه دفاعاً. .

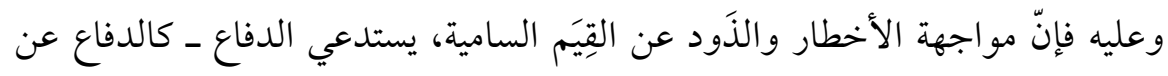
النفس والعِرض والمال والوطن، في حالة الاعتداء عليها من قِبل أعدائه المناوئين له، وفي سبيل

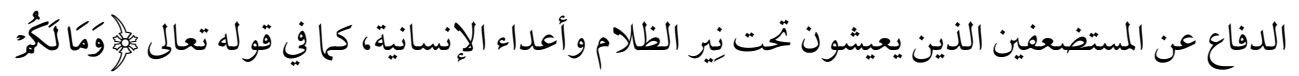

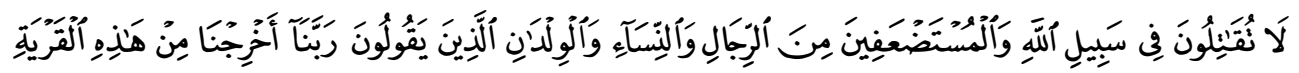

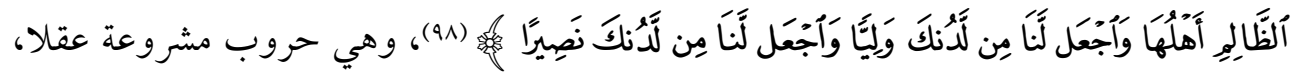
وليس لها مثيل في العالم في حاضره وماضيه في شدّة مر اعاتها للحقوق الإنسانية، وهي حروب كناب كانت

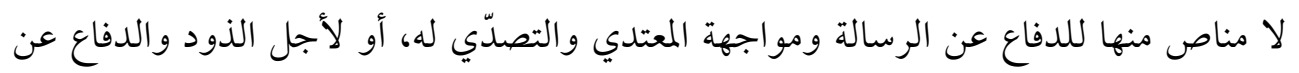

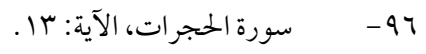

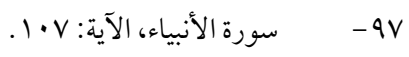

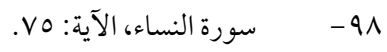




$$
\text { النفس... وغيرها من مسوّغات الحرب. }
$$

لذا فالقاعدة والأساس في الإسلام هو السلام، والحرب ماتها هي إلّا استثناء وعند

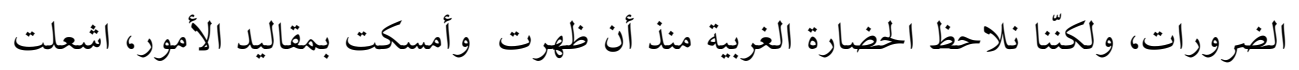

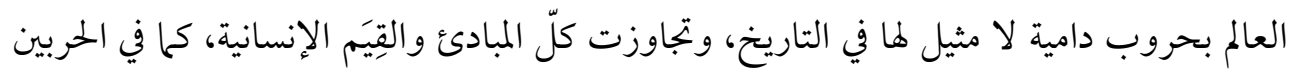

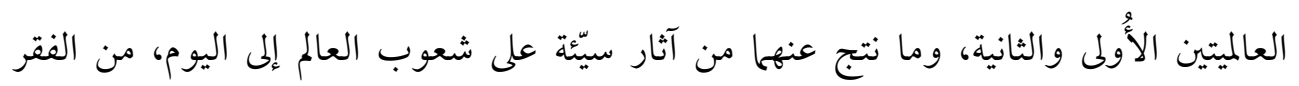

$$
\text { والاستعار و التشتّت والضغائن ما بين بني البشر. }
$$

وعلى هذا فالفتوحات الإسلامية تُعتبر قضاء على الظلم و الطغيان الحاصل من المتسلّطين بنّين على الشعوب، وهي مع ذلك دعوة للمجتمعات في اعتناق الدين الإسلامي باختيارهم من دون

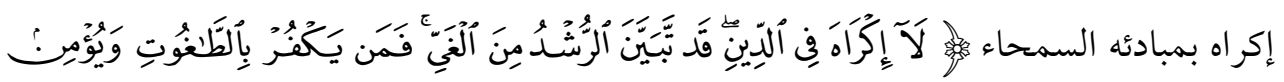

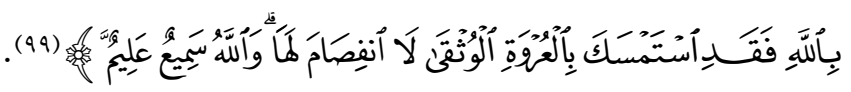

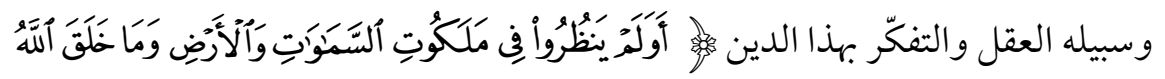

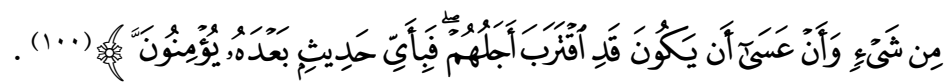
وفي المقابل إذا وقف أحد بأساليب عدوانية أمام هذه الدعوة المسالمة ، كأن يكون عذّب مَنْ

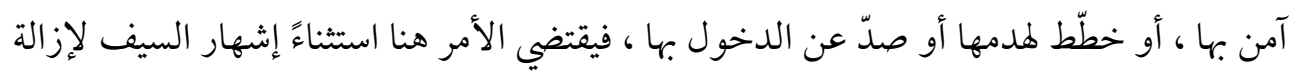
هذهِ العقبة فقط ، فعلى سبيل المثال : قتال المسلمين للروم في موقعة مؤتة في عصر النبي عليه السلام،

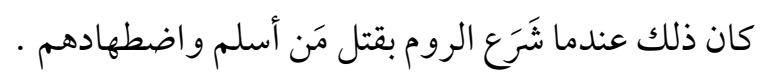

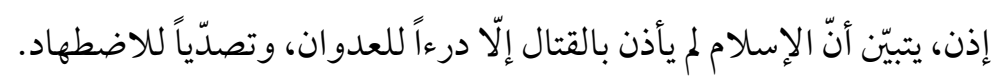
قضية حقوق الإنسان

\begin{tabular}{|c|c|}
\hline سورة البقرة، الآية: ror. & -99 \\
\hline سورة الأعراف، الآية: 1101. & $-1 \cdot$ \\
\hline
\end{tabular}
هناك قضية أخرى، وهي قضية حقوق الإنسان، والتي تبنتها البشرية منذ عدة عقود، 
وتقوم الدول الكبرى باستخدامها سياسيا ضد الدول الصغرى، ولكن الإسلام تحدث عنها وتبناها مبكرا، ذلك إن قضية حقوق الإنسان من أهم القضايا المثارة في العصر الحديث، وقد كثر عنها الكلام وتعددت المفاهيم، وتنوعت الرؤى، ثم صدر الإعلان العالمي لحقوق الإنسان من منظمة الأمم المتحدة(1.1) لتضع الشعوب أمام مسؤولياتها لضمان حقوق الحرية والعمل والسفر (r.1) ، وغيرها من الحقوق التي نص عليها الإعلان، ورغم كل ذلك مازالت تلك الحقوق منتهكة في دول العالم ، والدول الكبرى على وجه الخصوص تنتهك حقوق الحقوق الإنسان في العالم بأسره ، ثم تستخدم تلك الحقوق للضغط على الشعوب الأخرى من أجل تنفيذ سياساتها ، ولذا ظلت حقوق الإنسان حبراعلى ورق.

إن الدول الكبرى تفتخر بأنها أرست حقوق الإنسان في أرضها، وتعتقد أن حقوق

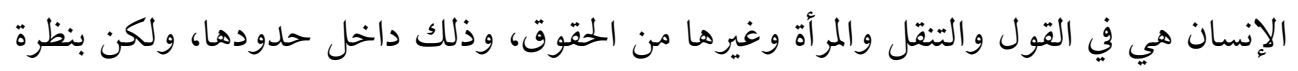
متأملة يجد الإنسان أن كثيرا من حقوق الإنسان داخل تلك الدول منتهكة، وعلى سبيل المثال مازال يوجد تمييز ضد السود في المجتمعات البيضاء، كما أن العهال في تلك الدول مازالو اليعانون من سوء العلاقة بينهم وبين أصحاب الشركات الكبرى والمتعددة، وهي شركات رأسمالية ضخمة، تتدخل

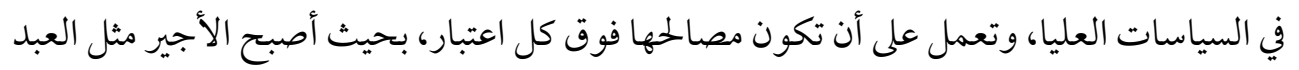

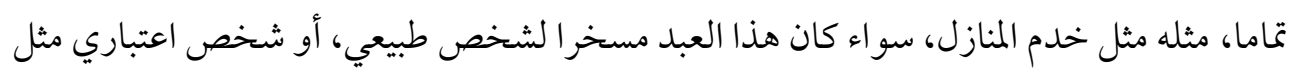

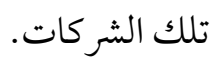

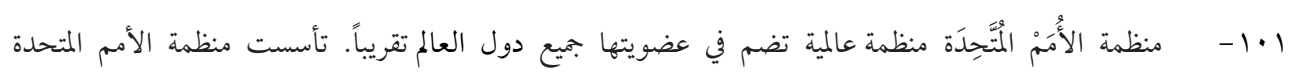

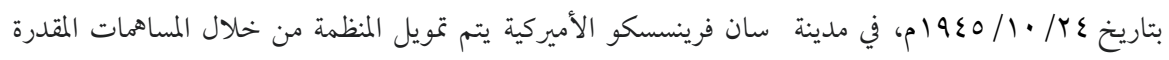

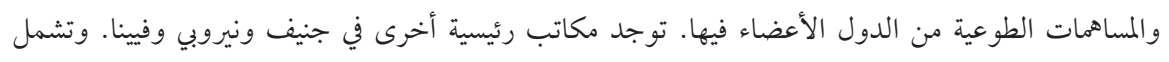

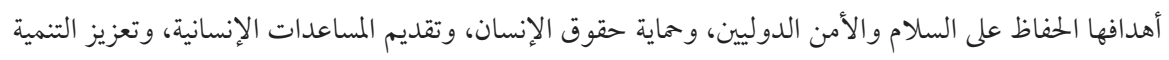
المستدامة، ودعم القانون الدولي الموسوعة الحرة ويكيبديا. صدر الإعلان العالمي لحقوق الإنسان، عام 19 19 م. $-1 \cdot r$ 


\section{موقف الإسلام من حقوق الإنسان}

إن الأديان جميعا جاءت بالحرية للإنسان من استعباد الآخرين له، الحكام وغير الحكام،

وقد سبقت الأديان كل المفاهيم البشرية لتلك الحقوق، ولأن الإسلام هو خاتم الرسالات فلابد أنه أعطى الإنسان حقوقه كاملة غير منقوصة، وما جاء في القرآن الكريم وسيرة الرسول الأكرم سبق الإعلان العالمي بألف وأربعهائة عام، ولأن الإسلام إلهي المصدر فقد تميز ما جاء فيه عن غيره،

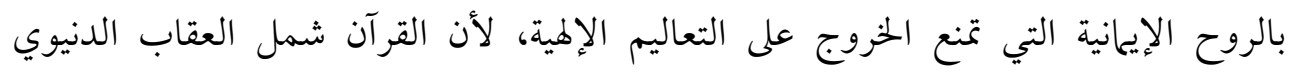

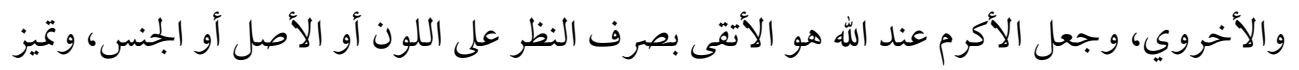

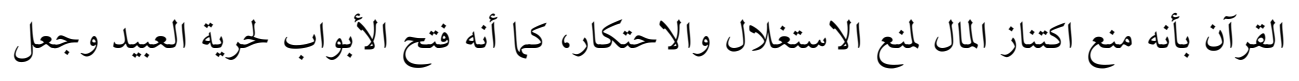
معاملة الرقيق هي نفس معاملة السيد.

إن الإنسان خخلوق مكرم من الله العلي القدير، كما أن الله خلق الإنسان في أحسن صورة

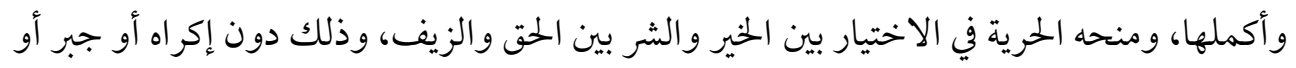
تعذيب أو قتل، فكانت تلك أول الحقوق الممنوحة للإنسان، لأنه مخلوق على الفطرة السوية

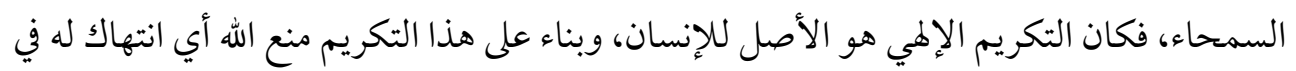
البدن أو الروح، ولذا ومنذ بدء الخليقة وحتى قيام الساعة، ما انفكت حقوق الإنسان هي المحور

$$
\text { الأبرز في الفلسفات الوضعية والتشريعات الإلهية. }
$$

لقد بُعث الأنبياء والرسل بشرائع السماء من أجل رفعة الإنسان والارتقاء به إلى الكمال التي حددها الله سبحانه له ، وهو الحق مصدر الحقوق كافة ، إلا أن تلك الحقوق قد تجاذبتها الأهواء

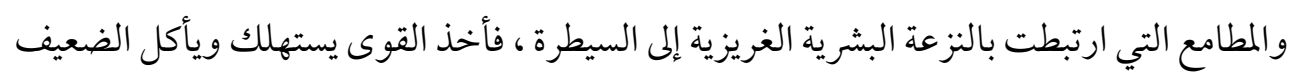
بحكم القوة التي امتلكها أو يحاول امتلاكها على حساب الآخرين. ورغم التطور البشري والحضاري الذي ساد المجتمعات لم يتخلص الإنسان من هموم البحث عن الطعام أو العمل أو السلطة وهو ما أدى إلى استمرار الأقوياء يستخدمون الأرقاء كعبيد 
مسخرين لخدمتهم سواء في المنازل كخدم أو عمال في المزارع والمصانع يأخذون أجورا متدنية لا

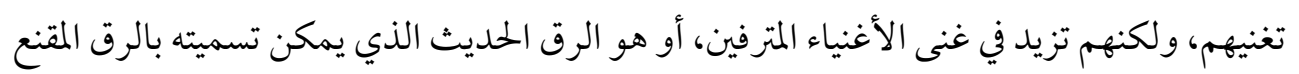

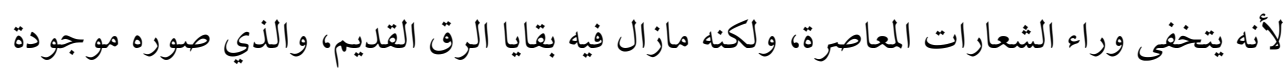
على مستوى الأفر اد وعلى مستوى الجماعات، كما نشاهده في استغلال الأطفال و النساء، وكما نشاهده في استغلال بعض الجماعات البشرية مثل ما حدث للسود الأفارقة الذين لا ذنب لهم سوى لون البشرة، وهم مازال يمارس ضدهم أنواع من التمييز العنصري. ولا يمكن الحديث عن حقوق الإنسان في القرآن الكريم دون التطرق للعدل، لأن العدل هو الأصل الذي يصون كل الحريات والحقوق والو اجبات، وبدونه تصبح الحقوق مهدرة، ولأهمية العدل في الإسلام وردت مادة (العدل) في القرآن الكريم ^ب مرة، ووردت كلمة (القسط) المرادفة

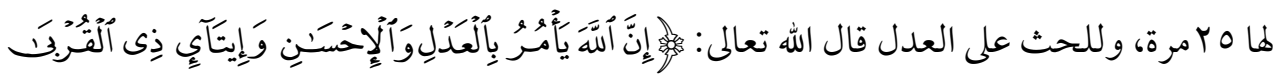

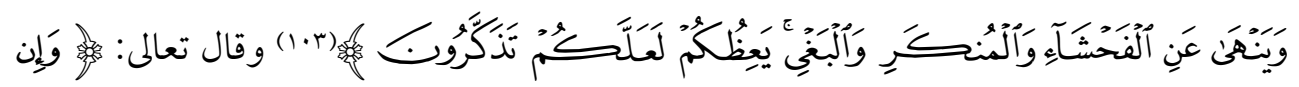

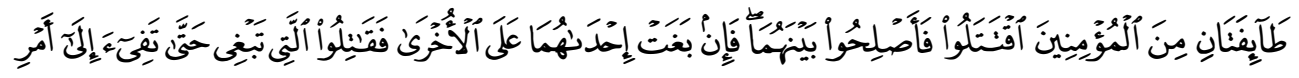

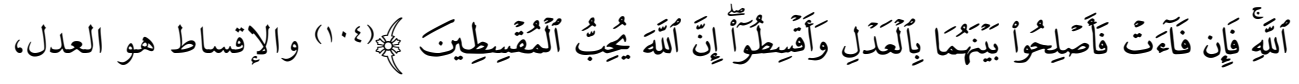

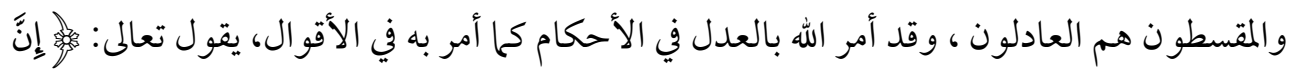

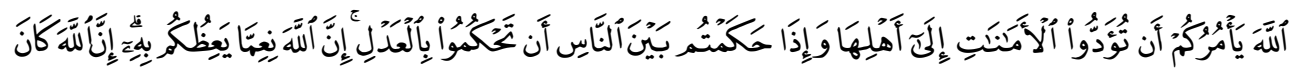

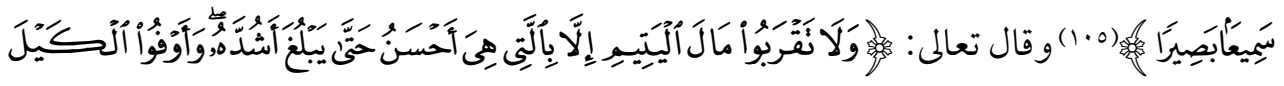

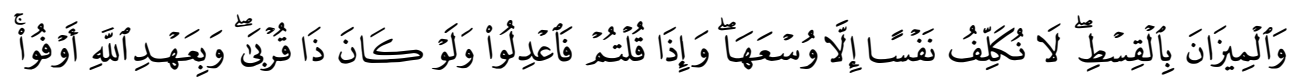

$$
\text { ع.1. } 1 \text { س سورة النحل، الآية: •9. }
$$




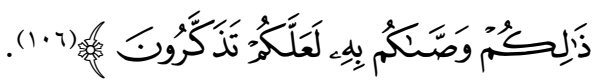

لقد كانت البشرية قبل بزوغ فجر الإسلام تعرف العدوان أكثر مما تعرف الحق، وتحترم

القوة أكثر مما تحترم الحرمة، والإنسانية في ظلمات بعضها فوق بعض، يفتك القوي بالضعيف،

ويأكل القادر حقوق العاجز، ومع ذلك عرف العرب في جاهليتهم حلف الفضول، أن ينصروا المظلوم ويقفوا معه حتى يأخذ حقه من الظالم ، وذلك الحلف الذي قال فيه الرسول صلى الله عليه

$$
\text { وسلم: "لو دعيت إليه في الإسلام لأجبته"(v•). }
$$

وجاءت رسالة الإسلام، رسالة العدل والمساواة، حيث أشرقت الأرض بنور ربها وارتفعت كلمات رسول الله صلى الله عليه وسلم يوم حجة الوداع: "إن دماءكم وأموالكم و أعراضكم عليكم حرام كحرمة يومكم هذا في شهركم هذا في بلدكم هذا"(^•1). ذلك هو النهج القرآني الأصيل في حقوق الإنسان، وهو منهج نحن مأمورون باتباعه، ولو فرطنا فيه نكون فرطنا في الدين والكرامة الإنسانية كلها، وهذا هو المنطق القرآني الحواري في التعامل بين المسلمين بعضه البعض، وهي نظرة الإسلام لغير المسلمين، من أهل الكتاب ومن غير أهل الكتاب، حقوق مصونة وروح معصومة، وحياة كريمة لإنسان كرمه الله. موقف الإسلام من الغير

الإسلام كما قلنا يعتمد الحوار بين المسلمين بعضهم البعض، وبين المسلمين وغير المسلمين، ثم أعطى الحقوق لكل البشر، ومن هنا نرى أن الإسلام يقف من غير المسلمين في حال السلم موقف الأمان، بل إنه لم ينه عن البر بهم مادامو الم يقاتلوا المسلمين، وإنها ينهى عن البر بالذين قاتلوا المسلمين في دينهم وأخرجوهم من ديارهم وظاهروا على إخراجهم، فقال جل شأنه: لًَ لَ

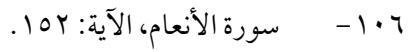

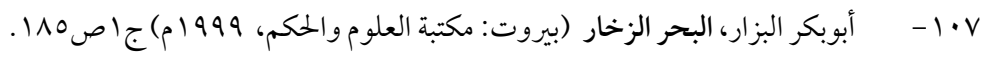

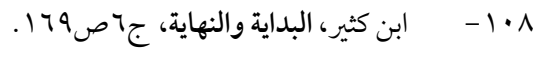




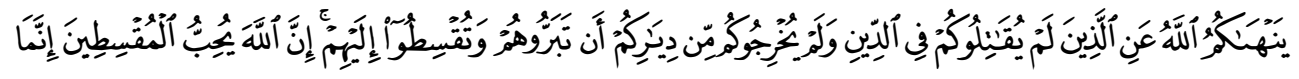

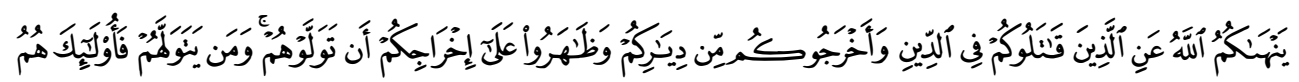

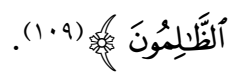
ونهى القرآن الكريم عن بجادلة أهل الكتاب إلا بالتي هي أحسن، فقال الله سبحانه:

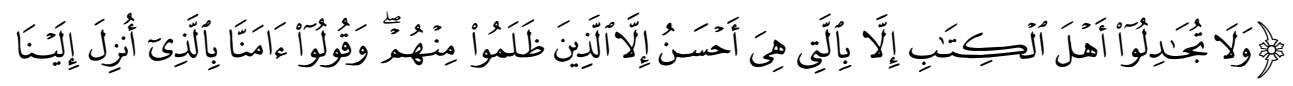

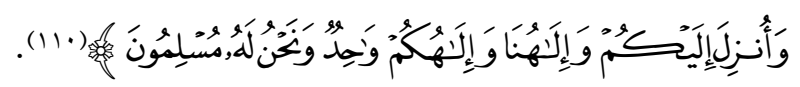

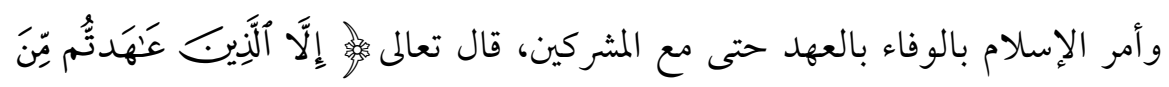

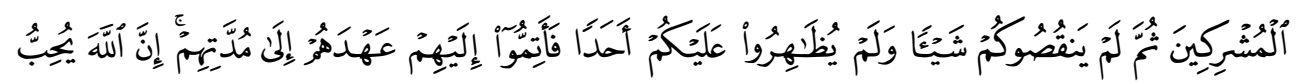

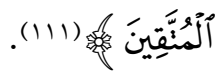

ولو طلب المشرك من المسلم أن يييره فعليه أن ييجيره، بل ويبلغه مأمنه، كما قال الله تبارك

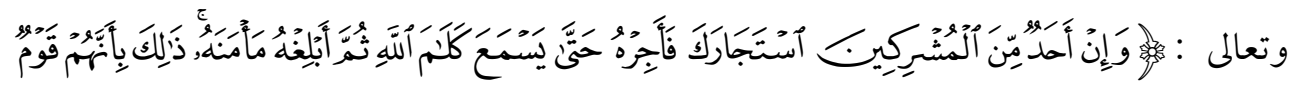

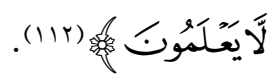

ومن رعاية الإسلام لحقوق غير المسلمين رعايته لمعابدهم وكنائسهم، ومن محافظته عليها

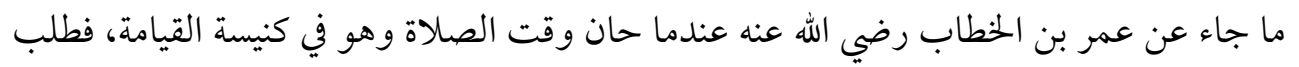
البطريرك من عمر أن يصلي بها، وهمّ أن يفعل ثم اعتذر ووضح أنه يخشى أن يصلي بالكنيسة فيأتي

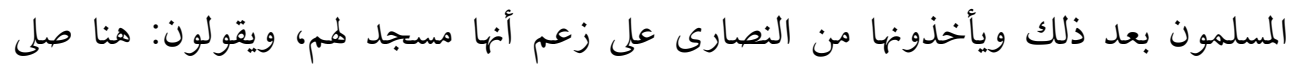

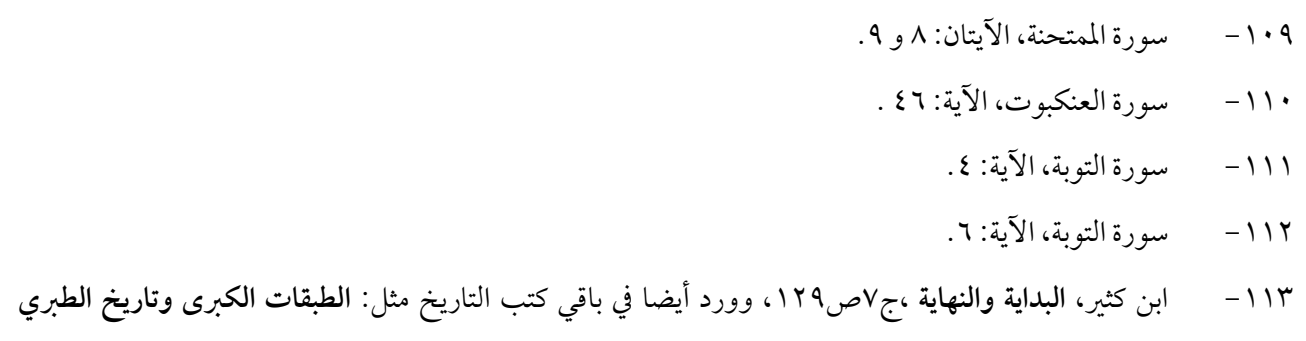


ولم تتوقف معاملة المسلمين لغير المسلمين عند حد المحافظة على أموالهم وحقوقهم، بل حرص

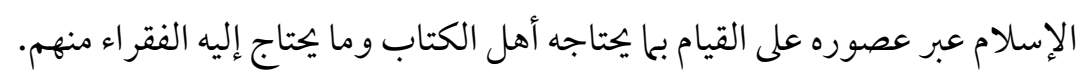

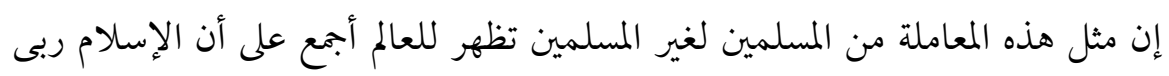
أتباعه على التسامح، وعلى رعاية حقوق الناس، وعلى الرحمة بجميع البشر مها اختلفت عقائدهم وأجناسهم.

وقد حفظت أجيال المسلمين قيمة هذه الرعاية الإسلامية لحقوق غير المسلمين، لأنهم ما طبقوها إلا استجابة لتعاليم القرآن الكريم، وتوجيهات الرسول، وقد طبقها في حياته كما كتبنا في

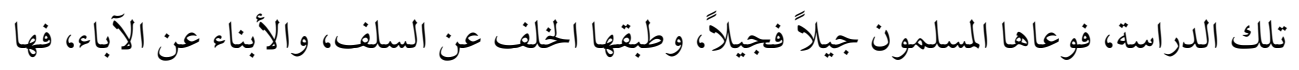
هو ذا عبد الله بن عمر رضي الله عنها: حدث بجاهد قال: "كنت عند عبد الله بن عمر، وغلام لم

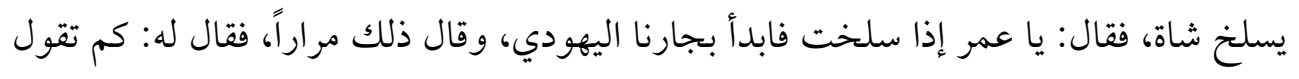

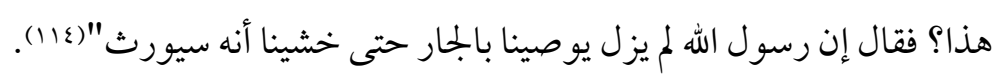

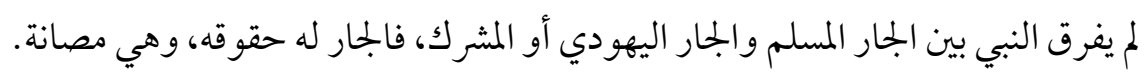

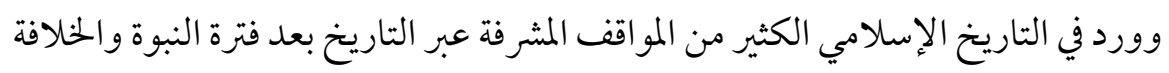
الر اشدة، التي تؤكد النظرة الإسلامية الحقيقية لغير المسلمين في البلاد الإسلامية.

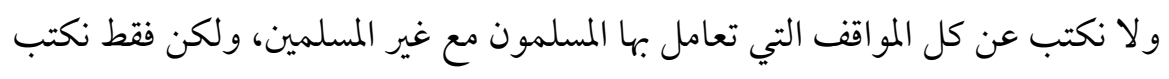
عن مجمل فكر التسامح والتعامل الإسلامي مع غير المسلم.

$$
\text { وغيرهما من كتب التاريخ الإسلامي. }
$$

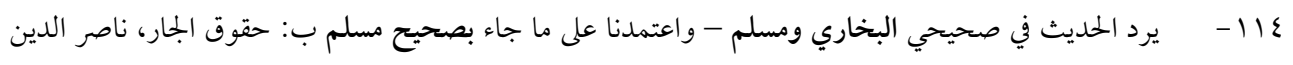

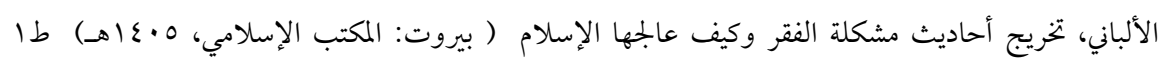

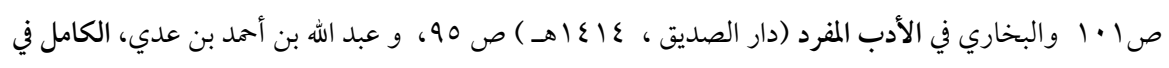

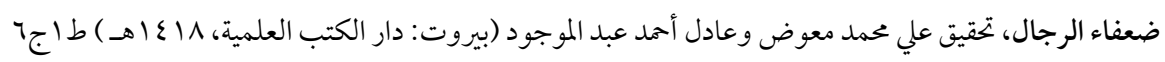
ص rar 
ولقد صل الأمر أن الفقهاء قالوا بأنه واجب المجتمع الإسلامي أن تُوَمَّن كل ضوابط

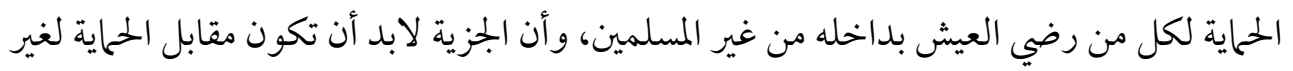

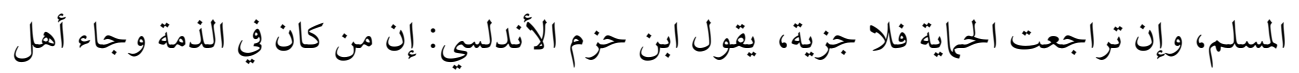

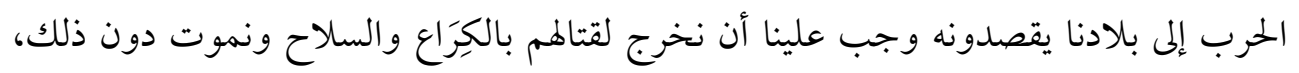
صوناً لمن هو في ذمة الله تعالى، وذمة رسوله، فإن تسليمه دون ذلك إهمال لعقد الذمة (110)، وهو

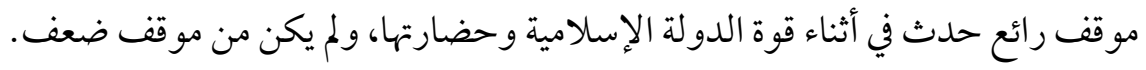

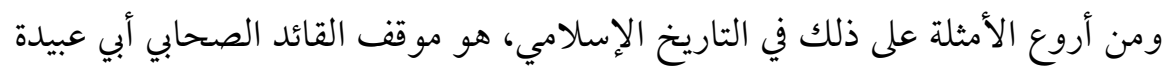
بن الجراح رضي الله عنه من أهل حمص وغيرهم عندما كان يفتح بلاد الشام، فعندما هُزم المسلمون

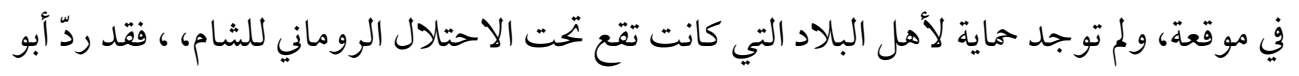

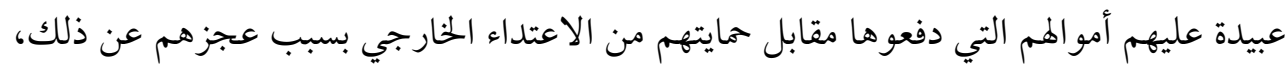
فُدهش هؤلاء القوم، ثم قال أهل محص لأبي عبيدة : ردكم الله إلينا ولعن الله الذين كانوا يملكونيا

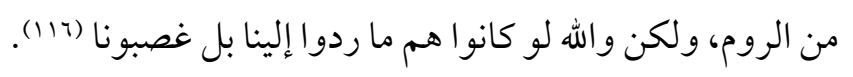

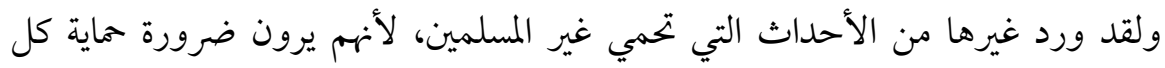

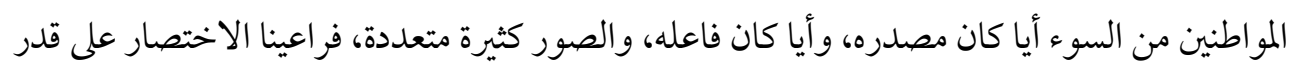

$$
\text { الدراسة البحثية. }
$$

تلك هي رؤية الإسلام لغير المسلمين، لا جبر ولا إكراه، ولا تكبر، ولا تحيز، وهو الموقف الواجب أن يتبناه المسلمون بين بعضهم البعض من جهة، وبينهم وبين غير المسلمين من جهة أخرى، ولو لم يحدث نكون كمن يبتعد عن رؤية القرآن وسنة النبي صلى الله عليه وسلم.

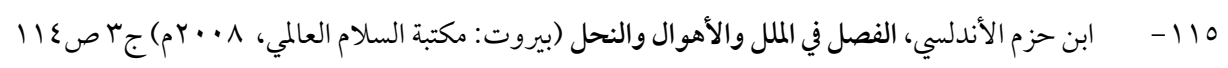

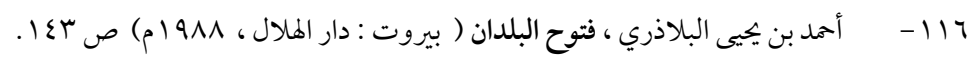


المطلب الثاني : طرق تعزيز الحوار وتقوتيه في العصر الحاضر عصر التقدم العلمي تتعدد الطرق التي تعزز وتقوي الحوار بين المسلمين بعضهم البعض، وبينهم وبين غيرهم من

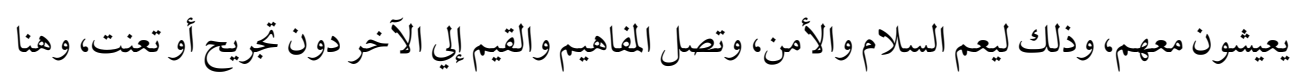
نكتفي بأهم تلك الطرق لأن المقام لا يتسع للتفصيل. أولا: المؤسسات الدينية

إن المؤسسات الدينية في شتى أرجاء العالم الإسلامي كـ "الأزهر الشريف، ووزارات الأوقاف والشئوون الإسلامية، ودور الإفتاء" لها دور مهم وعظيم في تقوية الحوار وتعزيزه بين المسلمين بعضهم البعض وبينهم وبين غيرهم من يعيشون معهم، وذلك من خلال عقد الحوارات والمؤتمرات وإصدار الكتب والمنشورات المختلفة والتي تحمل وسطية الإسلام دون إفر اط أو تفريط في ثوابت الدين، وقد كان للأزهر الشريف والأوقاف المصرية دور كبير في هذا الشأن فقد تم مثلا إنشاء "بيت العائلة" المصري بين الأزهر والكنيسة المصرية، ومبادرة "معنا في خدمة الوطن التي تعقد سنويا" بالتعاون بين واعظات الأوقاف وراهبات الكنائس لتصحيح كثير من المفاهيم الخاطئة لدى الآخر، كما أن هناك الكثير من الإصدارات التي صدرت في هذا

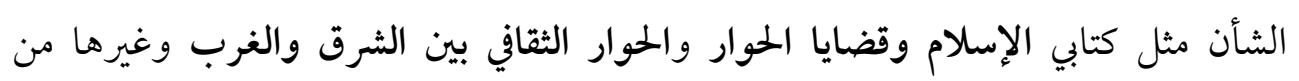
الإصدارات التي تقوي العلاقة وتزيل اللبس الخاطئ (vil) . ويتضح ما سبق أهمية دور المؤسسات الدينية في تعزيز وتقوية طرق الحوار وذلك من لمن

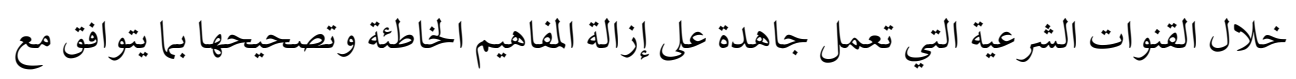
ما جاء به الشرع الحنيف، خاصة وأن هناك قيم ومبادئ تتفق عليها جميع الديانات فهي أصول

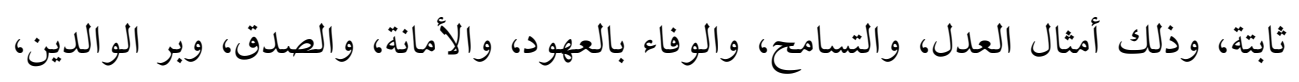

VIIV - الحوار الثقافي بين الشرق والغرب، إعداد الإدارة المركزية للسيرة والسنة بالمجلس الأعلى للشؤون الإسلامية

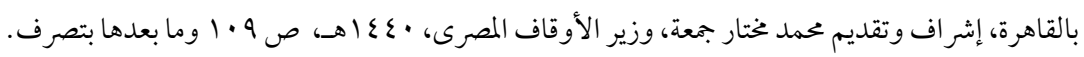


وحرمة مال اليتيم، وحق الجوار، والكلمة الطيبة، وغيرها من القيم التي تتفق عليها الشرائع ثانيا: وسائل الإعلام ولذام يقول النبي "الأنبياء إخوة لعلات، أمهاتهم شتى ودينهم واحد" (11).

تعتبر وسائل الإعلام المختلفة من أهم الطرق التي تقوي وتعزز الحوار بين الجمميع، بل

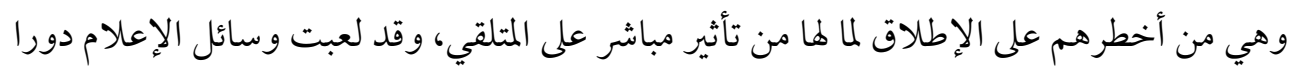
بارزا في حياة المجتمعات الإنسانية، ولهذا ارتبط الإعلام بكافة أنو اعه ووسائلة بمصطلح الرئي أئي العام، وهو أحد المصطلحات شائعة الاستخدام بين الكتاب والباحثين، ولم يأتِِ هذا الاهتحام الكبير من فراغ فقد أصبح الرأي العام الآن قوة لا يستهان بها في معظم دول العالم بها في ذلك الدول

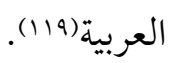

ويظهر جليا الدور الذي تلعبه تلك الوسائل في تغيير سلوك وأنماط المجتمع، والذي تبلغ قوته في بعض الأوقات الحد الأعلى في تشكيل الأخلاق والسلوك، ويرجع ذلك لعدة أسباب منها، قوة وضعف المو اد الإعلامية المقدمة للمتلقي، وقوة وانعدام الثقة فيما يقدم، واختلاف وجهات النظر.

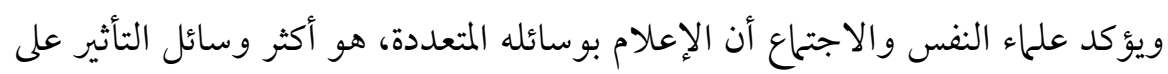

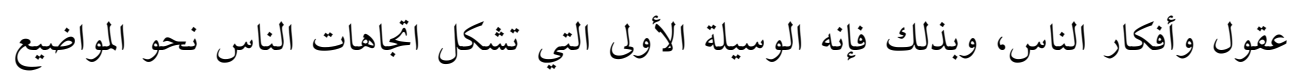
والمو اقف الحياتية اليومية التي تعيشها وتو اجهها المجتمعات العالمية، كما أصبح الإعلام يستخدم في لئي التنظيم والبناء الاجتماعي المتكامل من أجل مصلحة الفرد والمجتمع، وفق ما يراها صاحب الآلة الإعلامية(1) (Ir.)

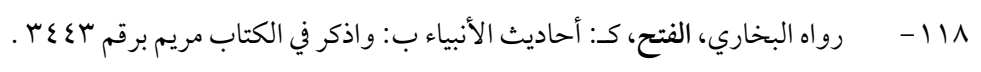

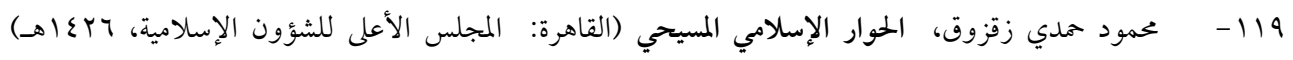
. 17.1V •

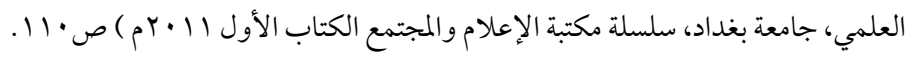


وهذا يوضح الدور الخطير الذي تلعبه وسائل الإعلام المختلفة في تشكيل الرأي العام خاصة في هذا العصر الذي نحياه عصر التقدم العلمي الرهيب والذي استطاع أن يجول العالم بأسره إلى قرية صغيرة تتناقل الأخبار أولاً بأول ولا يستطيع أحد أن يخفي شيئا.

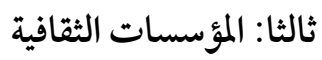
إن من الوسائل التي تقوي طرق الحوار وتعززه المؤسسات الثقافية، والتي تستطيع بدورها بناء جسور التفاهم بين الشعوب والأمم، فتنشر ثقافة التسامح والتعايش والوئام، سعيا لبناء سلام عالمي على قاعدة القانون الدولي والقيم الإنسانية الخالدة، والتي هي القاسم المشترك بين الأديان

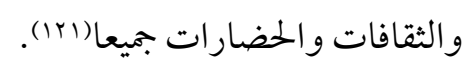

وتتعدد المؤسسات الثقافية والمنظمات الثقافية في العالم، وأصبح لها وزارات وهيئات كثيرة متنوعة، تعمل جميعها على نشر الثقافة والعلم ولكن على اختلاف التوجهات الدولية، فهي جميعها

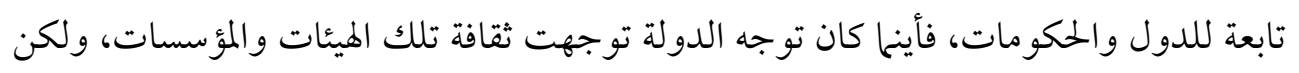
لابد أن نعلم أن لتلك المؤسسات دوراً هاماً في بناء جسور الحوار بين المسلم وغيره. رابعا: المؤسسات التعليمية

المؤسسات التعليمية لها دور هام وبارز في إقامة حوار هادف وبناء، وتدعم الجهود المبذولة في هذا الإطار، إن الوعي بالمشترك الأخلاقي والإنساني والقيمي هو في حقيقته التحقيق العملي

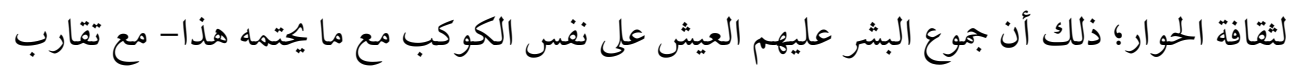
المسافات بفعل التقدم التقني في وسائل المو اصلات والاتصال- من ضرورة التعاون، فالو اقع يبين

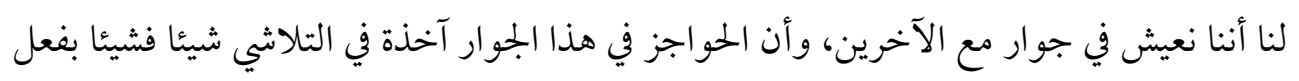

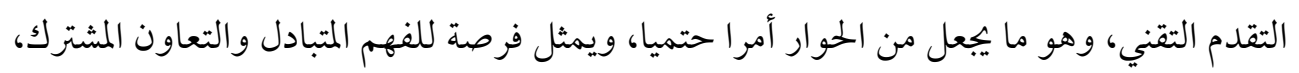

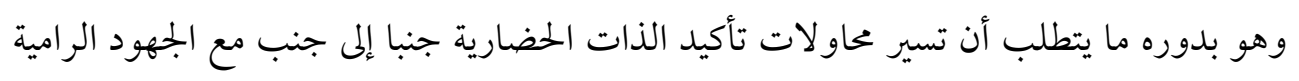


لتوسيع آفاقنا الفكرية؛ ذلك أن بجرد إبراز أخطاء الآخرين فقط يؤدي إلى إفشال الحوار وتفريغه من

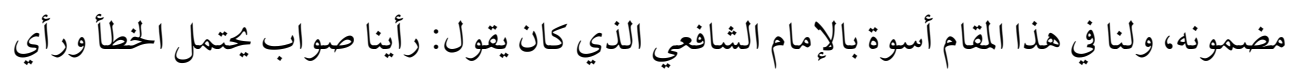

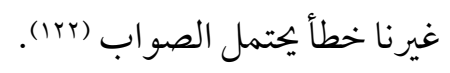
ولا شك إن المؤسسات التعليمية في الشرق والغرب يقع على عاتقها تبني مناهج وسياسات تعليمية توضح هذا المشترك الأخلاقي والقيمي للإنسان، وتؤكد على أهميته

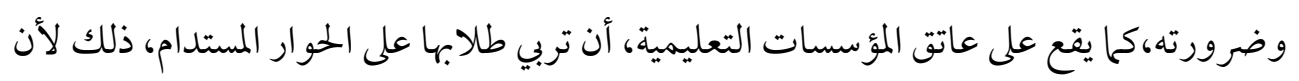
مهمتها ليست فقط تنشئة الفرد المتعلم والمهني الكفء ، بل التنشئة على المواطنة في مجتمع تعددي عبر توطيد أواصر العيش المشترك الثقافي والديني بين الأفراد والمجتمعات، فلابد للمؤسسات بهات التعليمية من دور في تشكيل المجتمع وثقافته. هذه أهم الوسائل والطرق التي تستطيع أن تقوي وتعزز طرق الحوار بين المسلمين بعضهم البعض، ويبنهم وبين غيرهم كمن يعيشون معهم. الخاتهــــة

الحمد لله الذي بنعمته تتم الصالحات، والصلاة والسلام على من أرسله ربه رحمة للعالمين، سيدنا محمد صلى الله عليه وسلم، وعلى آله وصحبه الطبيين الطاهرين، وعلى من تبعهم إلى يوم الدين ـ وبعد:

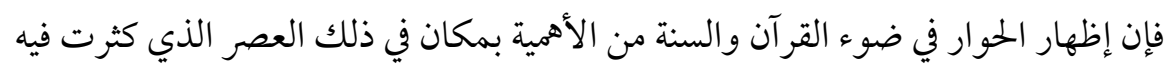
المذاهب والأحزاب، وتعالت فيه روح الاختلاف والفرقة على جميع جوانب الحياة الإسلامية.

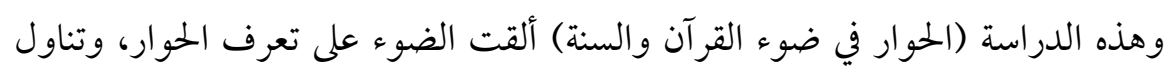

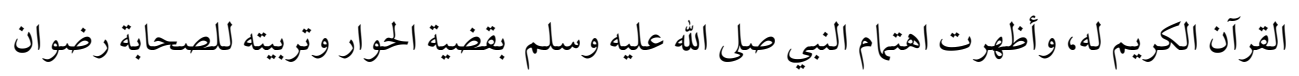

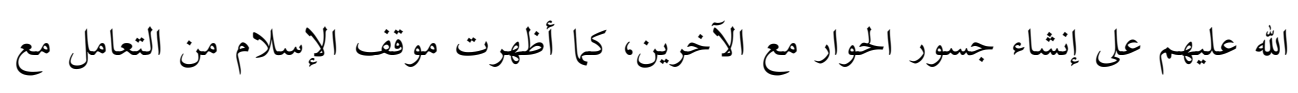
الآخرين، وأهم الوسائل والمؤسسات التي لها دور بارز في تقوية وتعزيز الحوار.

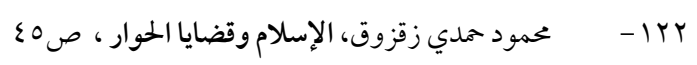




$$
\text { أهم النتائج التي توصل لها البحث نجملها في نقاط : }
$$

1 - الحوار أهم وأنجح الوسائل التي يستخدمها المرء لتحقيق أهدافه والتعبير عن أفكاره،

ولذلك نجد أن القر آن الكريم اعتمده كثيراً في عرض الأحداث ، فالقرآن - بلا شك-

$$
\text { يرسم منهجاً متكاملاً للحوار. }
$$

r - اهتم النبي صلى الله عليه وسلم اهتماما بالغا بقضية الحوار وعلمه لأصحابه رضوان الله

$$
\text { عليهم. }
$$

ب- الإسلام دين الحوار ولذلك لم يقتصر الحوار في الإسلام على المسلمين، وإنحا تعداهم إلى

$$
\text { حوارهم مع الغير ووضع لذلك ضو ابط وشروطاً. }
$$

$$
\text { r- الإسلام أول من قرر حقوق الإنسان قبل نشأة المنظمات الحقوقية. }
$$

ع - يمتاز الحوار القرآني بتنوع الأساليب التي يستخدمها في عرض مادة الحوار والكشف عنه

$$
\text { حسب ما يقتضيه الحال و السياق. }
$$




\section{List of References}

1. abbdullah bin āḥmad bin 'adī, al-kāmil fĩ dụ 'afā'i al-rijāl (beīrūt: dāru al-kutub al-'ilmīä̈, 1418 AH)

2. abū hâ̄mid al-ghazālī, iḥīà'u 'ulūmu al-dīn (dār al-minhāj, 2011 $\mathrm{AD})$

3. abūbakar al-bazār, al-baḥru al-zakhnār (beīrūt: maktabä̈u al-'ulūm wa al-hikam, 1999 AD)

4. āḥmad bin fâris al-qazwīnī, maqāī̄s al-lughä̈ ( beīrūt: dāru al-fikr, $1399 \mathrm{AH})$

5. āḥmad bin hạbal, musnadu al-īmām āḥmad bin ḥanbal (cairo: 'issa al-ḥalbī $1313 \mathrm{AH}$ )

6. Aḥmad bin yahīa al-balāḍarī, futūḥu al-buldān (beīrūt: dāru al-hilāl , 1988 AD)

7. aḥmad muḥammad al-sharqāwī, al-ḥiwār al-qur' ānī fĩ dạ̄'i sūräti al-'ān' 'àm ( jāmi 'ä̈u al-shāriqä̈)

8. aḥmad saīf tarkistānī, al-ḥiwār ma a aṣḥābi al-' adīān ( wazārë al'aūqāf al-sa 'ūdīä̈ 2019 AD)

9. aintiṣār ibrāhīm wa șafd husām, al-āi lām al-jadīd taṭaūru al$\overline{\mathbf{a} a d a \bar{i}} \mathbf{i}$ wa al-wasīlä̈ wa al-wazîfä̈ ( Ministry of Higher education and research, university of Baghdad,2011 AD)

10. Al-ḥiwār al-thaqāfĩ baīna al-sharq wa al-gharb, prepared by Central council of Religious affairs, Under the supervision of Dr. Muhammad Mukhtar, Minister for trust properties, Egypt, 1440 AH.

11. Ali abū al-khnaīr , al-rasūlu al-mușțafa ... thaūräu al-kalimä̈u almuqadasä̈ (ālqāhirä̈ :markazu al-fārābī lildirāsāt, 2007m )

12. 'alī abū al-khâ̄r, al-'aktharīä̈ wālijmā' fī tārīkh al-'aumä̈ ( baīrūt: markazu al-ḥaḍārä̈ litanmīäi al-fikri al-īslāmī, 2011 AD)

13. al-jurjānī, al-ta rîfāt (baīrūt: dāru al-kutub al-'ilmīaä)

14. al-qurțabī, muḥammad bin āḥmd, al-jāmi' l'āḥkāmu al-qur'ān (mū'sasä̈u al-risālä̈)

15. al-rāghib al-' āṣfahān̄̄, mufradātu al-fāẓu al-qur'ān (damishq: dāru al-qalam , 2009 AD)

16. al-sīid muḥammad ḥusaīn fạ̣lullah, mustaqbalu al-ḥiwāru alìslāmī (baīrūt : al-īslāmī 2004 AD).

17. al-zamzamī, al-ḥiwār: adābuh wa ḍawābiṭuh fì ḍaū'i al-qur'ān wa al-sunä̈ ( dāru al-tarbīä̈ wālturāth - ramādi $1414 \mathrm{AH}$ )

18. fahmī huwydī, ḥaqū al-nās hūa ḥaqū allah, majalä̈u al-'arabī alkawytīät - issue 297 - August, 1983 AD 
19. Human rights charter, 1948 AD

20. ibn kathīr, al-bidāīä̈ wālnihāīä̈ (ālqāhirä̈: dāru al-rīān llturāth, 1408 Ah. )

21. ibne jarīr al-țabarī, tārīkhnu al-rusul wa al-mulūk (ālqāhirä̈: dāru al-ma ārif, 2008 AD )

22. ibne abī shaībä̈, al-mușanif ( India: dā' ̄̄rä̈u al-ma ārif)

23. ibne ḥajar al-'asqalānī, al-īṣābä̈ fì tam̄̄z al-ṣaḥābä̈ (baīrūt: dāru al-kutub al-'ilmīä̈ 1995 AD)

24. ibne hajar al-'asqalān̄̄, muwāafqä̈u al-khabar ( Riyad: maktabä̈u al-rāshid,1419 AH)

25. ibne ḥazam al-' āndalusī, al-faṣl fī al-milali wa al-' āhwāli wa alnị̣al ( baīrūt: maktabä̈u al-salām al- 'ālamī, 2008 AD)

26. ibne hishām, al-sīrä̈u al-nabawīä̈ (ālqāhirä̈: dāru al-rīān lilnašr, 1987 AD )

27. ibne jarīr al-țabarī, jāmi u al-baīān fī tafsīr aī al-qur'ān (ālqāhirä̈ : dār ibne al-jaūzī)

28. ibne manzūur , lisānu al- 'arab (Cairo: dāru al-ma'ārif)

29. Mahmood Hamdi, al-ḥiwār al-īslāmī al-masīḥī (Cairo: Central council of Religious affairs, $1426 \mathrm{AH}$ )

30. maḥmūd shaltūt, al-īslām 'aqīdä̈ wa sharī' ä̈ (ālqāhirä̈: dāru alsharaūq lilnashr, 2007 AD)

31. muḥammad al-țāhir bin 'āshūr, al-taḥrīr wa al-tanwīr ( al-dāru altaūnsīä̈ lilnashr, 2008 AD)

32. muhammad bin īsmā'îl, al-' ādab al-mufrad (baīrūt:'ālamu alkutub, $1404 \mathrm{AH})$

33. muḥammad bin īsmā îl, ṣaḥīị al-bukhnārī (ālqāhirä̈: maktabä̈u alaslafīä $1400 \mathrm{AH}$ )

34. muhammad bin 'îssa abū 'īsa al-tirmidịi, sunan al-tirmidīi (baīrūt: dāru al-kutub al-'ilmīä)

35. muḥammad bin sa'ad al-zuhrī , al-țabaqātu al-kubra (ālqāhirä̈: maktabä̈u al-kh̄ānjī, 2001 AD )

36. muslim bin al-ḥajāj al-qashīrī, șaḥīị̣ muslim (ālqāhiraẗ: dār îhị̂à u al-kutub al-'arabīä̈, $1374 \mathrm{AH}$ )

37. rāghib al-surjānī, al-raḥmä̈u fĩ ḥaīäti al-rasūl ( dār rāghib alsurjānī lilnashr , 2009 AD)

38. sulaīmān bin al-'āsh 'ath, sunan ābū dāūd ((beīrūt: ālmaktabä̈ al'așrït ,2010 AD)

'umar bin 'abdullah kāmil, adābu al-ḥiwār ūqawā'idu al-āihntilāf (wazārtu al-' aūqāf al-sa 'ūdīä̈) 